\title{
Dnmt3a2 in the Nucleus Accumbens Shell Is Required for Reinstatement of Cocaine Seeking
}

\author{
- Nazzareno Cannella, ${ }^{1 *}$ (D)Ana M.M. Oliveira, ${ }^{2 *}$ Thekla Hemstedt, ${ }^{2 *}$-Thomas Lissek, ${ }^{2}$ Elena Buechler, ${ }^{1}$ \\ -Hilmar Bading, ${ }^{2}$ and ${ }^{-}$Rainer Spanagel ${ }^{1}$ \\ ${ }^{1}$ Institute of Psychopharmacology, Central Institute of Mental Health, Medical Faculty Mannheim/Heidelberg University, Mannheim 68159, Germany, and \\ ${ }^{2}$ Department of Neurobiology, Interdisciplinary Center for Neuroscience, Heidelberg University, Heidelberg 69120, Germany
}

Epigenetic mechanisms have gained increasing attention as regulators of synaptic plasticity and responsiveness to drugs of abuse. In particular, it has been shown that the activity of the DNA methyltransferase 3a (Dnmt3a) mediates certain long-lasting effects of cocaine. Here we examined the role of the Dnmt isoforms, Dnmt3a1 and Dnmt3a2, within the nucleus accumbens (NAc) on transcriptional activity of immediate early genes (IEGs) and acute and long-lasting responsiveness to cocaine and cocaine conditioned cues. Using primary striatal cultures, we show that transcription of Dnmt3a2, but not that of Dnmt3a1, is activated by dopamine D1 receptor signaling and that knockdown of Dnmt3a2 using viral vector-mediated expression of Dnmt3a2-specific shRNAs impairs induction of the IEGs, $\operatorname{Arc}$, Fos B, and Egr2. Acute cocaine administration increases expression of Dnmt3a2 but not that of Dnmt3a1 in the NAc shell. In contrast, in the NAc core, expression of Dnmt3a1 and Dnmt3a2 was unaffected by cocaine administration. shRNA-mediated knockdown of Dnmt3a2 in vivo impairs the induction of IEGs, including Egr2 and FosB indicating that Dnmt3a2 regulates cocaine-dependent expression of plasticity genes in the rat NAc shell. Cocaine self-administration experiments in rats revealed that Dnmt3a2 regulates drug cue memories that drive reinstatement of cocaine seeking as well as incubation of this phenomenon within the NAc shell. Dnmt3a2 does not influence the primary reinforcing effects of cocaine. Thus, Dnmt3a2 mediates long-lasting cocaine cue memories within the NAc shell. Targeting Dnmt3a2 expression or function may interfere with cocaine craving and relapse.

Key words: craving; DNA methyl transferase; epigenetic; psychostimulant; relapse; striatum

\section{Significance Statement}

In humans, drug craving can occur in response to conditioned cues, even after extended periods of abstinence. In rats, cue-induced cocaine seeking has been shown to increase progressively during the first 2 months of abstinence from drug self-administration. This phenomenon, referred to as incubation of cocaine seeking, is consistent with the hypothesis that in humans craving increases over time and remains high following prolonged abstinence. Those long-lasting behavioral changes are likely to be mediated by epigenetic effects and neuroplastic changes within the mesolimbic brain reward system. Here we show that a specific isoform of DNA-methyltransferases in the NAc shell regulates drug cue memories that drive reinstatement of cocaine seeking after both early abstinence and incubation of cocaine craving.

\section{Introduction}

Repeated exposure to addictive drugs induces neuroadaptations in the brain reward circuit that are believed to underlie both the

\footnotetext{
Received March 5, 2018; revised July 3, 2018; accepted July 9, 2018.

Author contributions: N.C., A.M.O., and T.H. wrote the first draft of the paper; N.C., A.M.O., T.H., H.B., and R.S. edited the paper; N.C., A.M.O., T.H., H.B., and R.S. designed research; N.C., A.M.O., T.H., T.L., and E.B. performed research; N.C., A.M.O., and T.H. analyzed data; N.C., A.M.O., T.H., H.B., and R.S. wrote the paper.

This work was supported by Deutsche Forschungsgemeinschaft Collaborative Research Center Grants SFB636 and SFB1134, Subprojects B05, C01, and C03. H.B. and A.M.M.0. are members of the Excellence Cluster CellNetworks at Heidelberg University. A.M.M.O. is a recipient of Deutsche Forschungsgemeinschaft Emmy Noether Grant OL 437/1-1.

The authors declare no competing financial interests.

*N.C., A.M.M.O., and T.H. contributed equally to this work.

Correspondence should be addressed to either of the following: Dr. Nazzareno Cannella, Institute of Psychopharmacology, Central Institute of Mental Health, Medical Faculty Mannheim/Heidelberg University, J5, Mannheim
}

development of compulsive drug-taking and the persistence of craving and relapse. These neuroadaptations result from the induction of transcriptional responses, which can have potentially long-lasting effects on neuronal structure and function (Nestler, 2013). Epigenetic mechanisms are considered important regulators of synaptic plasticity and experience-dependent behavioral changes (Robison and Nestler, 2011; Rudenko and Tsai, 2014).

68159, Germany, E-mail: nazzareno.cannella@zi-mannheim.de, nazzareno.cannella@unicam.it; or Dr. Ana M.M. Oliveira, Department of Neurobiology, Interdisciplinary Center for Neuroscience, Heidelberg University, Heidelberg Germany, E-mail: oliveira@nbio.uni-heidelberg.de.

N. Cannella's present address: School of Pharmacy, University of Camerino, Via A. D'Accorso, 16, 62032 Camerino MC, Italy.

DOl:10.1523/JNEUROSCI.0600-18.2018

Copyright $\odot 2018$ the authors $\quad 0270-6474 / 18 / 387516-13 \$ 15.00 / 0$ 
Further, epigenetic mechanisms may persistently affect gene expression, which ultimately can lead to long-term changes at the behavioral level. In particular, DNA methylation plays a critical role in cognitive functions (Oliveira, 2016) and may contribute to the persistence and maintenance of memories (Miller et al., 2010; Halder et al., 2016). Given the persistence of the associations between cues in a drug use environment and the rewarding effects of the drug, DNA methylation appears as a possible mechanism underlying this phenomenon and consequently the resilience of drug-seeking behavior. Indeed, cocaine exposure can induce transient and persistent changes in DNA methylation (Anier et al., 2010; LaPlant et al., 2010; Day et al., 2013; Baker-Andresen et al., 2015; Massart et al., 2015) that contribute to relapse and incubation of cocaine craving (LaPlant et al., 2010; Massart et al., 2015). Therefore, enzymes that catalyze DNA methylation or demethylation as well as proteins that read the methyl marks on the DNA may have important roles in drug-induced neuroadaptations within the reward system. The dynamic changes of methylation patterns depend on the activity of the de novo DNA methyltransferases (Dnmts) that add methyl groups to the DNA. These include the Dnmt3a and Dnmt3b (Moore et al., 2013). The Dnmt3a gene codes for two isoforms, Dnmt3a1 and Dnmt3a2 (Chen et al., 2002). The promoter of Dnmt3a2 is located in an intronic region of Dnmt3a; therefore, Dnmt3a2 protein is identical to Dnmt3a1, except that it lacks 219 amino acids at its $\mathrm{N}$ terminus (Chen et al., 2002). We previously found that expression of Dnmt3a2, but not that of Dnmt3a1, is regulated by neuronal activity in the mouse hippocampus and that Dnmt3a2 is required for long-term memory (LTM) formation (Oliveira et al., 2012) and for the extinction of fear memory (Oliveira et al., 2016).

Cocaine-associated environmental stimuli precipitate relapse, even after a prolonged period of withdrawal (O'Brien et al., 1992). It has been postulated that craving induced by drug-paired cues increases over weeks and months, which would account for this persistent relapse (Gawin and Kebler, 1986). Recent studies on craving induced by cocaine, methamphetamine, nicotine, and alcohol cues in addicts support this hypothesis (Bedi et al., 2011; Wang et al., 2013; Li et al., 2015; Parvaz et al., 2016). This phenomenon, known as incubation, is modeled in preclinical studies by exposing rats trained to operant cocaine (or other drugs) selfadministration and repeated reinstatement testing; the increase in reinstatement ratio expressed over prolonged withdrawal is considered a measure of incubated cocaine craving (Grimm et al., 2001). Incubation of cocaine craving is mediated by molecular and synaptic adaptation occurring in the NAc during withdrawal (Conrad et al., 2008; Loweth et al., 2014); however, we recently demonstrated that also synaptic adaptations developing during cocaine self-administration (CSA) training persist during abstinence and influence relapse and incubation of craving (Luís et al., 2017). In the NAc, Dnmt3a activity is associated with cocaine seeking; during abstinence, its expression is altered; and pretreatment with methylation inhibitors reduces reinstatement of cocaine seeking (LaPlant et al., 2010; Massart et al., 2015). However, the contribution of the two Dnmt3a isoforms to cocaine seeking and their potential role in incubation of cocaine craving is unknown. In this study, we investigated whether the de novo Dnmts, Dnmt3a1 and Dnmt3a2, are regulated by cocaine exposure in the NAc. Given the role of Dnmt3a2 in experience-dependent behavioral changes, we have also investigated the role of Dnmt3a2 in cocaine-seeking behavior.

\section{Materials and Methods}

Animals

Male Sprague Dawley rats (Charles River) were 10 weeks old at the beginning of experimental procedures. Sprague Dawley rats were chosen because they are less sensitive than other lines to environmental factors affecting cue-responding (Oberhofer and Noori, 2017). Rats were single housed under $12 \mathrm{~h}$ dark/light reverse cycle in a temperature $\left(22 \pm 1^{\circ} \mathrm{C}\right)$ and humidity $(60 \pm 5 \%)$ controlled room. Subjects had ad libitum access to food and water in their home cages throughout their permanence in the facility. Experimental procedures were conducted during the dark phase of the light-dark cycle and were in accordance with the Directive 2010/63/EU Guidelines for care and use of laboratory animals.

\section{Recombinant adeno-associated viruses ( $r A A V s$ )}

Viral particles were produced and purified as described previously (Zhang et al., 2007). To drive the expression of the shRNAs, a rAAV vector containing the U6 promoter for shRNA expression and a chicken $\beta$-actin promoter to drive GFP expression were used. The Dnmt3a2targeting shRNA sequence and control sequence have been described previously (Oliveira et al., 2012). Dnmt3a2-targeting shRNA sequence recognizes the $5^{\prime}$ UTR sequence unique to the Dnmt3a2 sequence (Oliveira et al., 2012).

\section{Primary striatal cultures}

Striatal neurons were prepared from neonatal C57BL/6N mice and cultured as previously described for hippocampal neurons (Bading and Greenberg, 1991), except that plastic dishes were coated with poly-Lornithine $(100 \mathrm{mg} / \mathrm{ml})$ in borate buffer. Experiments were performed at 11 DIV. rAAV infection of cultures was on DIV4.

\section{$q R T-P C R$}

RNeasy Plus Mini Kit (QIAGEN) was used for RNA isolation with additional on-column DNase I digestion according to the manufacturer's instructions. For the generation of cDNA, $1 \mu \mathrm{g}$ of total RNA was reverse transcribed with the High-Capacity cDNA reverse transcription kit (Invitrogen). qRT-PCR was performed on an ABI7300 thermal cycler using TaqMan gene expression assays (Applied Biosystems) for the following genes: Dnmt3a2 (Mm00463987_m1), Dnmt3a1 (Mm00432870_m1), Arc (Mm00479619_g1; Rn00571208_g1), FosB (Mm00500401_m1; Rn00500401_m1), and Egr2 (Mm00456650_m1). Expression levels of target genes were normalized to the expression of the housekeeping gene Gusb (Mm00446943_m1; Rn00566655_m1).

\section{Surgeries}

For self-administration experiments, rats were implanted with a MicroRenathane catheter (internal diameter: $0.58 \mathrm{~mm}$; external diameter: 0.94 $\mathrm{mm}$ ) inserted in the right jugular vein under isoflurane anesthesia. The proximal end reached the right atrium, whereas the back-mount passed under the skin and protruded from the mid-scapular region. Catheters were flushed daily with a heparinized solution ( $100 \mathrm{IU} / \mathrm{ml}$ ) containing $1 \mathrm{mg} / \mathrm{ml}$ of enrofloxacin (Baytril). Animals were given 1 week recovery before cocaine self-administration (CSA) sessions began. rAAV-control-shRNA or rAAVdnmt3a2-shRNA was stereotaxically delivered bilaterally into the NAc shell (NAcSh; coordinates from bregma: anteroposterior $1.6 \mathrm{~mm}$, mediolateral $\pm 0.7 \mathrm{~mm}$, dorsoventral from skull surface $-7.0 \mathrm{~mm}$ ). Coordinates were taken from Paxinos and Watson (1998) and adapted for the body weight of the animal. Experimental procedures started at least $21 \mathrm{~d}$ after viral infusion.

\section{Drugs}

Cocaine hydrochloride was purchased from Sigma-Aldrich and dissolved in sterile isotonic saline. The D1 receptor agonist SKF38393 (Tocris Bioscience) was dissolved in DMSO. The D1 receptor antagonist SCH-23390 (Tocris Bioscience) was dissolved in water.

\section{Self-administration apparatus}

Self-administration chambers ( $40 \mathrm{~cm}$ long $\times 30 \mathrm{~cm}$ wide $\times 52 \mathrm{~cm}$ high) were located in sound-attenuating cubicles equipped with exhaust fans to assure air renewal. Two poke holes were on opposite walls of the chambers, $5 \mathrm{~cm}$ above the grid floor. When rats poked their snout in the holes, breaking an infrared beam, their instrumental responding was recorded. 
One hole was associated with cocaine delivery and designated as the active hole, whereas the other was designated as the inactive hole and served as control. A white cue light was located $9.5 \mathrm{~cm}$ above the active hole, and a blue light was on the left side of the opposite wall $33 \mathrm{~cm}$ above the grid floor. A speaker allowing presentation of a tone cue was located in the middle of the back wall $40 \mathrm{~cm}$ above the greed floor. Data were collected with Windows-compatible SK_AA software (Imetronic).

\section{Behavioral methods}

CSA training and cue-induced reinstatement after acute and prolonged withdrawal were adapted from the incubation of cocaine craving model described previously (Grimm et al., 2001; Conrad et al., 2008).

Self-administration training. Rats were 10 weeks old at the beginning of self-administration procedures. CSA training consisted of daily $6 \mathrm{~h}$ sessions during which nose-poking at the active hole under a fixed ratio 1 (FR1) of response was reinforced by $0.5 \mathrm{mg} / \mathrm{kg} /$ infusion of cocaine (infusion bolus: $40 \mu \mathrm{l}$ ). Cocaine availability was signaled by illumination of the blue light. Each earned infusion was coupled with $5 \mathrm{~s}$ presentation of two discrete cues (cue-light and $300 \mathrm{~Hz}$ tone, $60 \mathrm{~dB}$ ). All infusions were followed by a $40 \mathrm{~s}$ time-out, during which the blue light was turned off and drug was not available. Responding during time-out or poking at the inactive hole was recorded but resulted in no programmed consequences. Unless stated otherwise, infusions were limited to 25 injections per hour to avoid overdose risk. After the 25th infusion, the blue light signaling cocaine availability was turned off and nose-poking in either hole had no consequence until the beginning of the next hour.

Cue-induced reinstatement of cocaine seeking. Cue-induced reinstatement of cocaine seeking was tested at both withdrawal day 1 (WD1) and WD45 using a within-session extinction/reinstatement schedule, composed by an extinction phase followed by a reinstatement phase within the same session (Shaham et al., 2003). The session begun with extinction of cocaine seeking, during which responding to the cocaine-associated device was not reinforced and was not followed by any scheduled consequence. The extinction phase was maintained until the only extinction criterion applied was met. The extinction criterion was $<15$ active nosepokes during the last hour. Rats had a time window between a minimum of $1 \mathrm{~h}$ and maximum of $8 \mathrm{~h}$ to reach the extinction criterion; failing to do so caused the exclusion of the rat from the analysis. Immediately after this criterion was met, the program switched to the $1 \mathrm{~h}$ cue-induced reinstatement phase. Cue-induced reinstatement began with the illumination of the blue light and a single noncontingent presentation of the discrete cue-light; thereafter, everything was identical to a standard CSA session, except that cocaine was not delivered.

Experiment 1. We set out to investigate whether the expression of the de novo DNA methyltransferases, Dnmt3a1 and Dnmt3a2, is regulated by D1 receptors in striatal medium spiny neurons (MSNs). On DIV11, striatal cultures were treated with the D1 receptor agonist SKF38393 (10 $\mu \mathrm{M})$ or left untreated in the presence or absence of the D1 receptor antagonist SCH23390 $(10 \mu \mathrm{M})$. SCH23390 was added to the cultures 5 min before the SKF38393 treatment. Four hours later, the cells were harvested and processed for RNA extraction. $N=4$ independent cell preparations.

Experiment 2. Here we tested whether a cocaine challenge would induce Dnmt3a1 or Dnmt3a2 expression in the NAc core (NAcCo) and NAcSh. Rats were injected with either saline $(n=13)$ or cocaine (10 $\mathrm{mg} / \mathrm{kg}$ i.p. $)(n=19)$. One hour later, the saline group and one cocaine group $(n=10)$ were killed, the brains quickly removed and fresh-frozen in isopentane. Three hours after treatment, also the second cocaine group $(n=9)$ was subjected to the same procedure. NAcCo and NAcSh were punched out and used for gene expression analysis by qRT-PCR.

Experiment 3. We then tested whether operant CSA would induce Dnmt3a1 or Dnmt3a2 expression patterns in NAcCo and NAcSh similar to that observed in Experiment 2. Rats were divided into six groups, of which three were subjected to CSA training and three were kept as agematched cocaine-naive controls. One cocaine and one naive group $(n=$ 7 or 8 each) were killed, and their brains harvested $24 \mathrm{~h}$ after $1 \mathrm{~d}$ of CSA. The other two cocaine groups concluded $10 \mathrm{~d}$ of CSA training. The second cocaine and naive groups ( $n=8$ each) were killed $24 \mathrm{~h}$ after the last day of CSA. The last two groups ( $n=7$ each) were killed after $45 \mathrm{~d}$ of withdrawal. Rats were guillotined, brains were quickly removed and fresh-frozen in isopentane. NAcCo and NAcSh were punched out and used for gene expression analysis by qRT-PCR.

Experiment 4. Next, we investigated whether cue-induced reinstatement of cocaine seeking alters Dnmt3a1/2 expression in the NAcCo and NAcSh. Of four groups of rats ( $n=6$ or 7 each), two groups where kept as age-matched cocaine-naive control, whereas the other groups were subjected to $12 \mathrm{~d}$ of CSA training. Of the two CSA groups, one group was killed $24 \mathrm{~h}$ after the cue-induced reinstatement test run at WD1 and accordingly named the WD2 group. The other group performed cueinduced reinstatement test at both WD1 and WD45 and was killed $24 \mathrm{~h}$ after WD45 and accordingly named the WD46 group. At each time point, a cocaine-naive group was killed as control and brain were processed as described in Experiment 3.

The next step was to evaluate whether Dnmt3a2 downregulation would affect CSA, cue-induced reinstatement and incubation of reinstatement of cocaine seeking.

Experiment 5. We tested whether Dnmt3a2 downregulation in the NAcSh would influence cue-induced reinstatement after prolonged withdrawal. Rats were subjected to CSA training and reinstatement testing at WD1. Twenty-four hours later, we injected Dnmt3a2shRNA $(n=$ $10)$ or rAAV-control-shRNA $(n=9)$ in the NAcSh, and then rats were returned to their home cage until a new cue-induced reinstatement test was run at WD45.

Experiment 6. Here we tested the effect of Dnmt3a2 downregulation on CSA, motivation for cocaine, cue-induced reinstatement, and incubation of cocaine craving. In this experiment, we transduced 7-week-old rats with Dnmt3a2-shRNA $(n=10)$ or control $(n=8)$; and 3 weeks later, at the usual age of 10 weeks, self-administration training started. Because in this experiment Dnmt3a2 was downregulated before any cocaine exposure, we determined whether this manipulation affected the primary reinforcing effects of cocaine. For this purpose, from the fifth CSA session, the maximum number of rewards allowed every hour was increased from 25 to 30 . This allowed us to observe the phenomenon of escalation of cocaine intake maintaining a safety limit against overdose risk. After $12 \mathrm{~d}$ of CSA, rats were tested in a progressive ratio (PR) session on day 13 . The PR test followed the protocol we described previously (Cannella et al., 2017, 2018). Briefly, the ratio of response was increased after each infusion according to the following progression: 10, 20, 30, 45, 65, 85, $115,145,185,225,275,325,385,445,515,585,665,745,835,925,1025$, $1125,1235,1345,1465,1585,1715,1845,1985,2125,2275,2425,2585$, $2745,2915,3085,3265,3445,3635,3825,4025,4225$. The last ratio completed is referred to as the break point and used to score motivation for cocaine. The session ceased after $5 \mathrm{~h}$ or if $1 \mathrm{~h}$ passed from the last infusion earned. After the PR test, rats were subjected to an additional $6 \mathrm{~d}$ of baseline CSA, and then they were tested for cue-induced reinstatement of cocaine seeking at WD1 and WD45 as described above.

Finally, in Experiments 7 and 8, we tested whether Dnmt3a2 modulates the expression of three immediate early genes (IEGs) involved in cocaine seeking (Fosnaugh et al., 1995; Larson et al., 2010; Gao et al., 2017).

Experiment 7. This in vitro experiment aimed at investigating whether Dnmt3a2 is required for the expression of the genes Arc, FosB, or Egr2 upon D1 receptor activation. On DIV4, the striatal cultures were infected with rAAV-control-shRNA or rAAV-Dnmt3a2-shRNA. On DIV11, striatal cultures were treated with the D1 receptor agonist SKF38393 $(10 \mu \mathrm{M})$ or left untreated (control condition). One, 3 , or $6 \mathrm{~h}$ later, the cells were harvested and processed for RNA extraction. $N=5$ independent cell preparations.

Experiment 8. The purpose of this experiment was to check whether gene expression in the NAcSh of these rats is consistent with cultured MSNs in Experiment 7. This experiment was run in NAcSh punches from all rats transduced with rAAV-Dnmt3a2shRNA or control viruses that received either an acute saline or cocaine (10 $\mathrm{mg} / \mathrm{kg}$ i.p.) challenge, as described in Experiment 2.

\section{Virus expression verification}

After each behavioral experiment that was not followed by gene expression analysis, the expression of the virus was verified. Animals that failed to express the virus or where virus expression was spread to other brain 
A

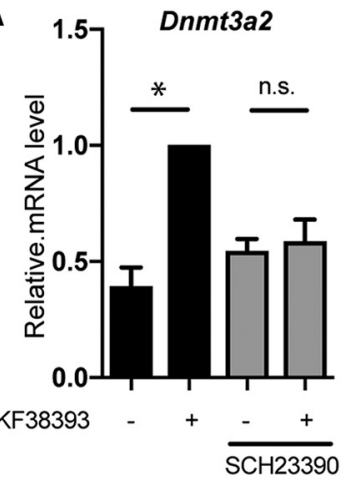

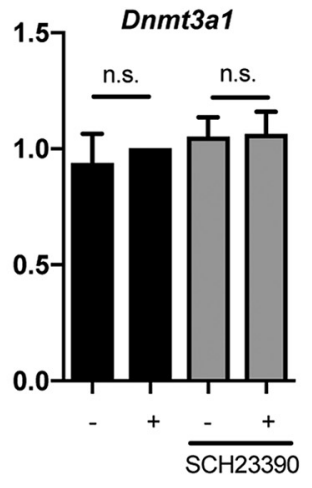

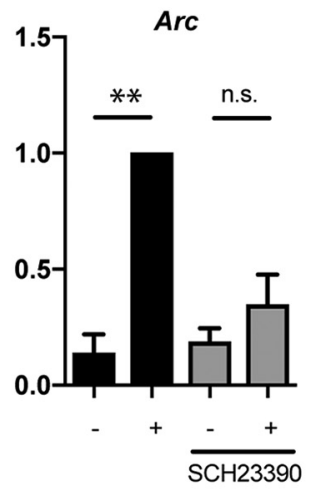

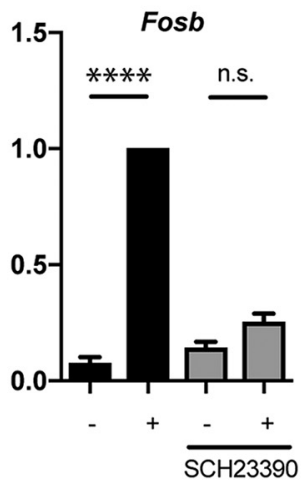

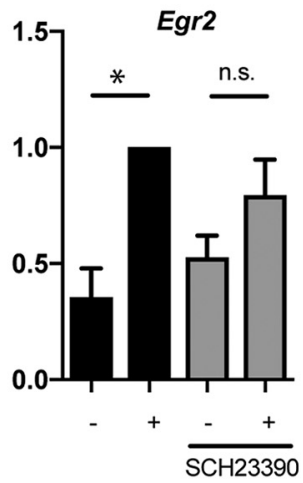

$\mathbf{B}$
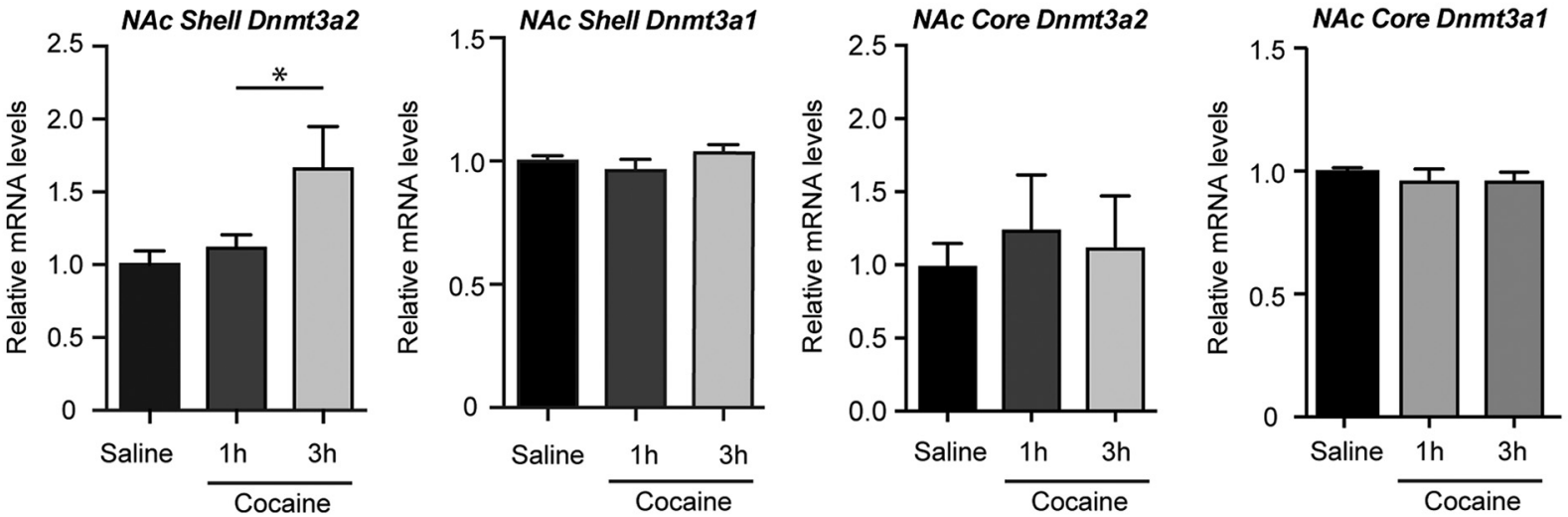

Figure 1. Gene expression analysis of Dnmt3a1 and Dnmt3a2 in primary striatal cultures and in NACSh and NAcCo. A, Primary striatal cultures were stimulated with the D1 receptor agonist SKF38393 in the presence and absence of the D1 antagonist SCH-23390. Dnmt3a2, Arc, FosB, and Egr2 mRNA levels, but not Dnmt3a1 mRNA levels, were increased by SKF38393 treatment. The presence of SCH-23390 abolished Dnmt3a2, Arc, FosB, and Egr2 expression induction. $N=4$ independent cell preparations. $B$, Gene expression analysis revealed an increase of mRNA Dnmt3a2 level in the NAcSh $3 \mathrm{~h}$ after cocaine treatment compared with saline-injected rats (left). Dnmt3a2 mRNA levels in the NAcCo (middle right), as well as Dnmt3a1 expression levels in the NAcSh (middle left) and NAcCo (right) were not altered by cocaine treatment. Saline, $n=13$; cocaine $1 \mathrm{~h}, n=10$; cocaine $3 \mathrm{~h}, n=9$. Data are mean \pm SEM. ${ }^{*} p<0.05 .{ }^{* *} p<0.01$. ${ }^{* * * *} p<0.0001$.

regions were excluded from the analysis. The tissue was processed as follows: rats were perfused with 4\% PFA (Sigma-Aldrich) and postfixed in the same solution overnight. Brains were then placed into a solution containing 30\% sucrose in $0.1 \mathrm{~m}$ phosphate buffer (PBS) containing $0.04 \%$ thimerosal (Sigma-Aldrich) for cryoprotection. Brains were cut at a thickness of $30 \mu \mathrm{m}$ and collected and stored in PBS containing $0.04 \%$ thimerosal until further process. Slices were washed two times with PBS for $5 \mathrm{~min}$ and incubated in Hoechst 33258 (1:5000) for $5 \mathrm{~min}$ and mounted on glass slides.

\section{Statistical analysis}

In the in vitro Experiment 1 , gene expression levels were analyzed by one-way ANOVA with repeated-measures and Bonferroni's correction for multiple comparisons. In Experiment 2, gene expression levels were also analyzed by one-way ANOVA. In Experiments 3-6, the number of infusions earned during training was analyzed by two-way ANOVA, with CSA days as repeated-measures and groups as between-subject factor. In Experiment 3, there were three groups in the first day, and number of infusion for that day was analyzed by one-way ANOVA with groups as between-subject factor. In Experiments 3 and 4, gene expression data were analyzed by Student's $t$ test. In Experiment 6, break point was analyzed by $t$ test for independent samples. In Experiments 5 and 6 , the number of active poking during the first hour of extinction was analyzed by two-way ANOVA with groups as between factor and withdrawal (WD1 vs WD45 time points) as repeated-measures. Cue-induced reinstatement was analyzed by four-way ANOVA with reinstatement-phase (extinction vs cue), withdrawal (WD1 vs WD45 time points), and nose-poking (active vs inactive) as repeated-measures and groups as between-subject factor. For Experiment 4, cue-induced reinstatement was analyzed twice. In one case, reinstatement at WD1 was compared between WD2 and WD46 groups by three-way ANOVA, with reinstatement-phase and nose-poking as repeatedmeasures and groups as between-subject factor. In the other case, reinstatement expressed by WD46 group on WD1 and WD45 tests was compared by three-way ANOVA with reinstatement-phase, nose-poking, and withdrawal as repeated-measures. ANOVAs were followed by Newman-Keuls post hoc analysis when appropriate. Active poke responding during the first hour of extinction on WD1 was compared between WD2 and WD46 groups by $t$ test for independent groups. Active poke responding produced during the first hour of extinction by WD46 group on WD1 and WD45 were compared by $t$ test for dependent samples. In Experiment 7, gene expression levels were analyzed by repeated-measures two-way ANOVA followed by Bonferroni's multiple comparison test. In Experiment 8, gene expression data were analyzed by two-way ANOVA followed by Tukey's post hoc test. Statistical significance was set at $p<0.05$. Data are mean \pm SEM.

\section{Results}

Experiment 1

We started by investigating whether D1-mediated dopamine signaling in cultured striatal neurons regulates the expression of the de novo DNA methyltransferases Dnmt3a1 and Dnmt3a2. We stimulated primary striatal cultures with the D1 receptor agonist SKF38393 in the presence and absence of the D1 antagonist SCH23390 (Fig. 1A). We observed that the expression of Dnmt3a2 is induced by SKF38393 treatment and that this was prevented by preincubation with the $\mathrm{D} 1$ antagonist $\left(F_{(1.7,5.1)}=12.12, p=\right.$ $0.013,-\mathrm{SCH} /-\mathrm{SKF}$ vs $-\mathrm{SCH} /+\mathrm{SKF}, p=0.01 ;+\mathrm{SCH} /-\mathrm{SKF}$ vs $+\mathrm{SCH} /+\mathrm{SKF}, p>0.99)$. In contrast, the expression of Dnmt3a1 was not altered by either treatment $\left(F_{(1.9,5.8)}=0.74, p=0.51\right.$, 
A

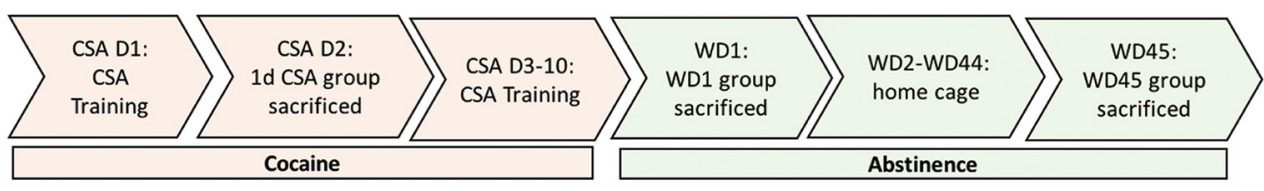

B

CSA training

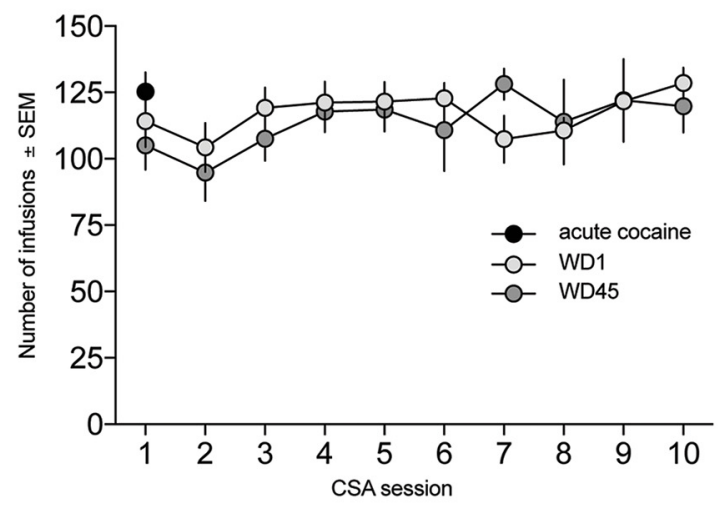

C

NAc Shell - 1d CSA

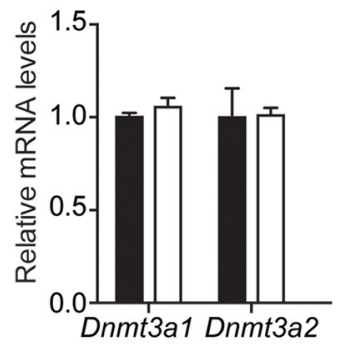

NAc Core - 1d CSA

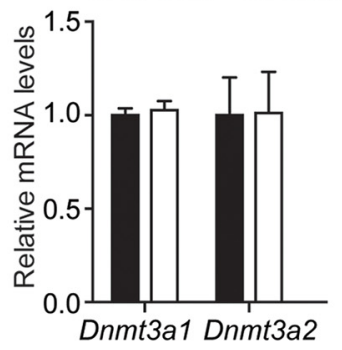

Age Control

NAc Shell - WD1
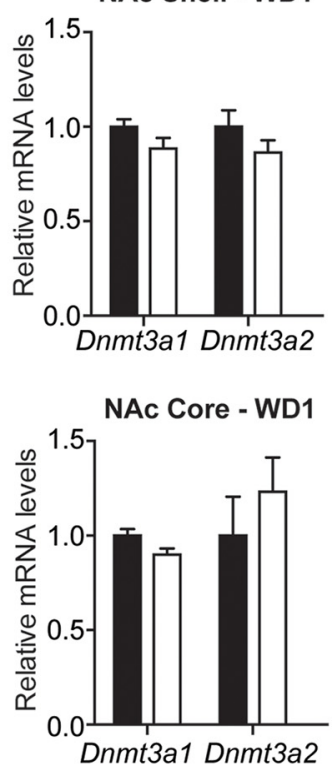

CSA
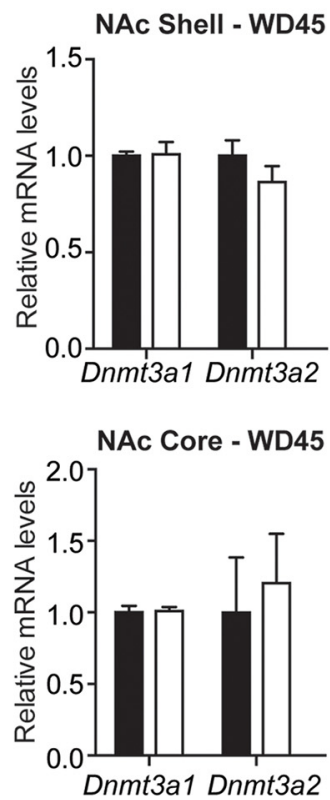

Figure 2. Gene expression analysis of Dnmt3a1 and Dnmt3a2 in the NAcSh and Core $1 \mathrm{~d}$ after a single CSA session (acute cocaine) and $1 \mathrm{~d}$ (WD1) and 45 $\mathrm{d}$ (WD45) after discontinuation of CSA training. $\boldsymbol{A}$, Schematic outline of the experimental design. $\boldsymbol{B}$, Acute-cocaine group ( $n=7$ or $8 /$ group) did not differ in number of cocaine infusions from WD1 ( $n=8 / \mathrm{group}$ ) and WD45 ( $n=7 /$ group) in their first CSA training session. WD1 and WD45 groups had a comparable CSA training. C, Acute cocaine and CSA training did not change the expression levels of Dnm3a1 and Dnm3a2 in the NAcSh and $\mathrm{NACC}$.

$-\mathrm{SCH} /-\mathrm{SKF}$ vs $-\mathrm{SCH} /+\mathrm{SKF}, p>0.99 ;+\mathrm{SCH} /-\mathrm{SKF}$ vs $+\mathrm{SCH} /+\mathrm{SKF}, p>0.99)$. We also confirmed the regulation of expression by $\mathrm{D} 1$ activation of the well-characterized immediate early genes $\operatorname{Arc}\left[F_{(1.2,3.7)}=49.87, p=0.0027,-\mathrm{SCH} /-\mathrm{SKF}\right.$ vs $-\mathrm{SCH} /+\mathrm{SKF}, p=0.0034 ;+\mathrm{SCH} /-\mathrm{SKF}$ vs $+\mathrm{SCH} /+\mathrm{SKF}, p=$ $0.24], \operatorname{FosB}\left[F_{(2.1,6.3)}=266.3, p<0.0001,-\mathrm{SCH} /-\mathrm{SKF}\right.$ vs $-\mathrm{SCH} /+\mathrm{SKF}, p<0.0001 ;+\mathrm{SCH} /-\mathrm{SKF}$ vs $+\mathrm{SCH} /+\mathrm{SKF}, p=$ $0.13]$ and $\operatorname{Egr} 2\left[F_{(1.8,5.4)}=13.36, p=0.0085,-\mathrm{SCH} /-\mathrm{SKF}\right.$ vs $-\mathrm{SCH} /+\mathrm{SKF}, p=0.03 ;+\mathrm{SCH} /-\mathrm{SKF}$ vs $+\mathrm{SCH} /+\mathrm{SKF}, p=$ 0.07] (see also Experiments 7 and 8). These findings show that Dnmt3a2 transcription, but not Dnmt3a1, is activated by dopaminergic signaling in striatal neurons.

\section{Experiment 2}

We next investigated whether Dnmt3a2 expression in the rat NAc is regulated by cocaine treatment. We administered cocaine acutely (10 mg/kg i.p.) and analyzed gene expression in the NAc 1 or $3 \mathrm{~h}$ after injection (Fig. $1 B$ ). We observed that cocaine administration increases expression of Dnmt3a2 (one-way ANOVA: $F_{(2,28)}=3.82, p=0.0342$, Bonferroni post hoc test, saline vs cocaine $3 \mathrm{~h} ; p=0.0266$ ), but not Dnmt3al (one-way ANOVA: $\left.F_{(2,30)}=1.042, p=0.3650\right)$, in the NAcSh $3 \mathrm{~h}$ after administration (Fig. $1 B$ ). In contrast, cocaine administration did not induce changes in the expression of Dnmt3a1 or Dnmt3a2 in NAcCo (Fig. 1B). 
A

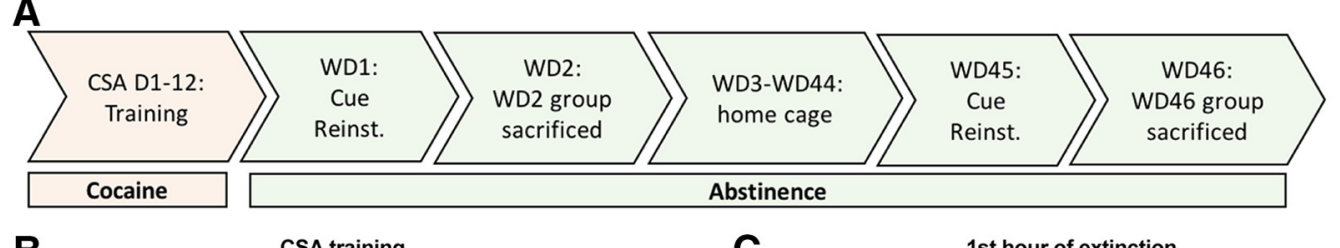

B

CSA training

C
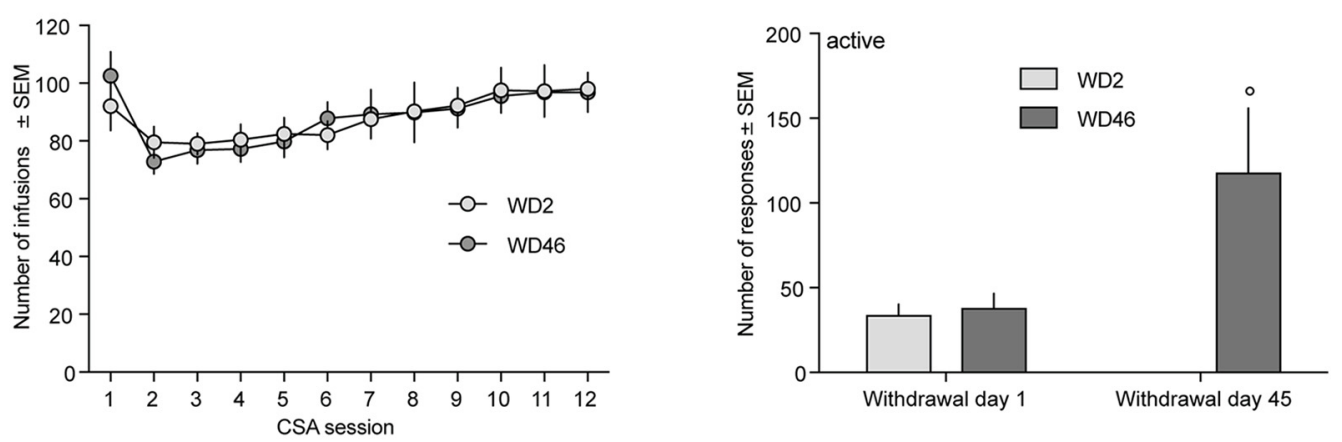

D
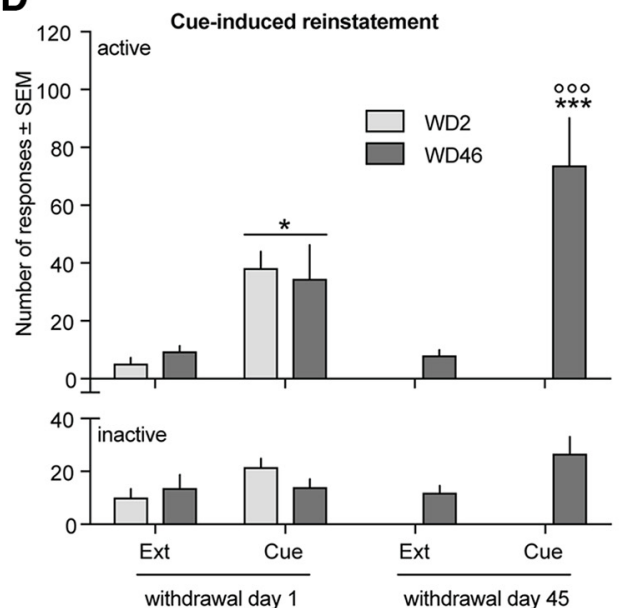

$\mathbf{E}$

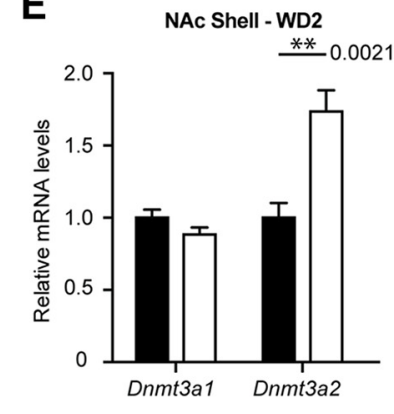

NAc Shell - WD46
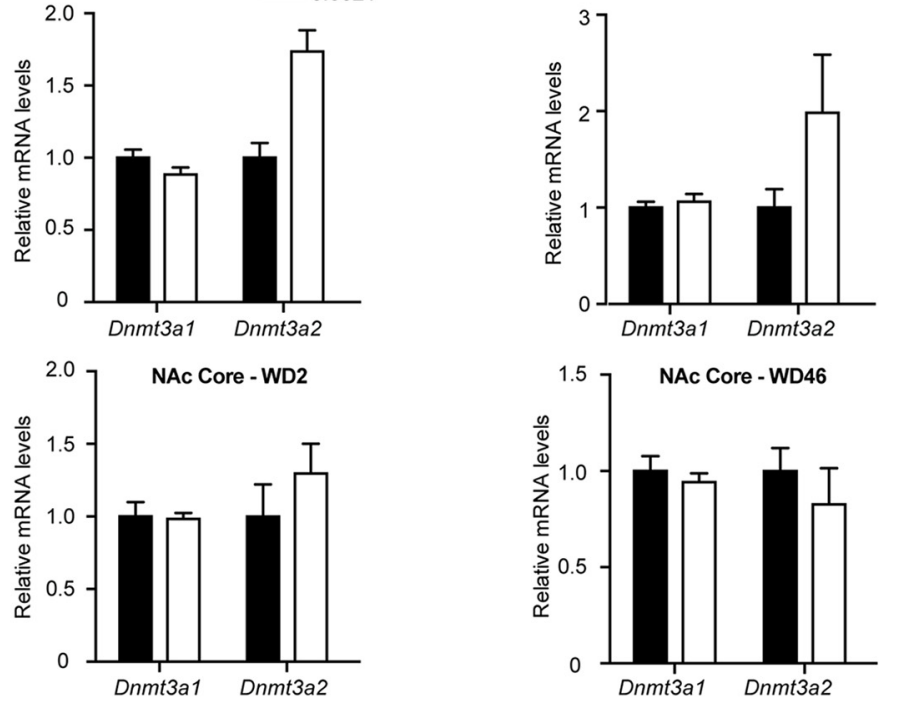

Figure 3. Gene expression analysis of Dnmt3a1 and Dnmt3a2 in the NAcSh and NAcCo $24 \mathrm{~h}$ after cue-induced reinstatement of cocaine seeking. $A$, Schematic drawing of the experimental protocol. $\boldsymbol{B}$, WD2 ( $n=6$ or $7 /$ group) and WD46 ( $n=6$ or $7 /$ group) rats killed, respectively, $24 \mathrm{~h}$ after reinstatement tests run at WD1 and WD45, did not differ in term of CSA. C, WD2 and WD46 groups did not differ in active poking during the first hour of extinction at WD1. Extinction responding incubated on WD46 group that increased active poking on WD45 respect to WD1. D, At WD1, presentation of cocaine-paired cues after extinction reinstated cocaine seeking in both groups of rats, which did not differ in terms of reinstatement ratio. WD46 groups repeated reinstatement test at WD45, where reinstatement ratio was higher with respect to WD1, which accounts for incubation of cocaine craving. Reinstatement and incubation effects (Figure legend continues.) 


\section{Experiment 3}

Next, we determined whether Dnmt3al/2 gene expression would be altered by cocaine also under operant conditions. For this purpose, we collected rat brains $24 \mathrm{~h}$ after $1 \mathrm{~d}$ of CSA, $24 \mathrm{~h}$ after the last day of chronic self-administration training (i.e., at WD1), and after WD45 (Fig. 2A). Analysis of the first CSA session found no overall effect of groups $\left(F_{(2,21)}=1.35 ; p=0.28\right)$. Similarly, there was no day $X$ group interaction when the whole CSA training performed by WD1 an WD45 was analyzed $\left(F_{(9,126)}=1.04\right.$; $p=0.41$ ) (Fig. $2 B$ ). This indicates that groups had comparable cocaine-intake history. We found no changes in the expression of Dnmt3a1, Dnmt3a2 in NAcSh or NAcCo in rats after CSA compared with age control rats (Fig. 2C).

\section{Experiment 4}

We then tested whether Dnmt3a1/2 gene expression is involved in conditioned reinstatement and incubation of cocaine-seeking behavior. The two groups of cocaine-exposed rats killed at WD2 and WD46 (see experiment's schematic representation in Fig. $3 A$ ) did not differ in terms of CSA (group $\times$ day interaction $\left[F_{(11,132)}=0.66 ; p=0.77\right]$, Fig. $\left.3 B\right)$. Active poking during the first hour of extinction on WD1 did not differ between WD2 and WD46 groups $\left(t_{(12)}=0.40 ; p=0.70\right)$. The WD46 group produced a higher active poking on the first hour of extinction on WD45 compared with WD1 $\left(t_{(6)}=2.57 ; p=0.042\right)$ (Fig. $3 C$ ).

Both groups of rats expressed a similar reinstatement ratio $24 \mathrm{~h}$ after the last cocaine exposure, at WD1 (nose-poking $\times$ reinstatement-phase interaction $\left[F_{(1,12)}=14.66 ; p=0.0024\right]$; nose-poking $X$ reinstatement-phase $\times$ groups interaction $\left[F_{(1,12)}=0.07 ; p=0.79\right]$ (Fig. $\left.3 D\right)$. The WD46 group repeated the cue induced reinstatement test at WD45. ANOVA found a significant withdrawal $\times$ reinstatement-phase interaction $\left(F_{(1,6)}=\right.$ 52.15; $p=0.00036)$. Thus, reinstatement responding at WD45 was significantly higher than reinstatement at WD1 $(p<0.001$; Fig. 3D). Both extinction and cue reinstatement scored by WD46 group indicate an incubation of cocaine craving (Grimm et al., 2001; Adhikary et al., 2017; Spanagel, 2017).

Gene expression analysis revealed that at WD2 Dnmt3a2 was increased in the NAcSh of cocaine-exposed rats in respect to cocaine-naive control rats $\left(t_{(10)}=4.108, p=0.0021\right)$ (Fig. $3 E$ ). Gene expression in the NAcSh at WD46 revealed a trend for increased Dnmt3a2 levels in CSA rats $\left(t_{(11)}=1.443, p=0.1769\right)$, albeit not significant (Fig. 3E). The expression levels of Dnmt3a1 were not affected by any of the experimental conditions. Gene expression in the NAcCo at both time points did also not differ between cocaine-exposed and cocaine-naive groups (Fig. $3 E$ ).

\section{Experiment 5}

Experiment 4 suggested that Dnmt3a2 expression in the NAcSh is upregulated following cue-induced reinstatement of cocaineseeking behavior. Here we investigated whether this upregulation influences reinstatement behavior. Therefore, we downregulated Dnmt3a2 expression by injecting rAAV-dnmt3a2-shRNA in the NAcSh immediately after the reinstatement test at WD1 (Fig. 4A)

\footnotetext{
$\leftarrow$

(Figure legend continued.) were specific for active poking. $\boldsymbol{E}$, Gene expression analysis revealed that, in rats killed at WD2, NAcSh Dnmt3a2 mRNA level was increased in cocaine-exposed rats in respect to cocaine-naive rats (top left). A similar trend was observed in rats killed at WD46, but the effect was not significant (top right). Dnmt3a2 and Dnmt3a1 expression levels in the NAcCo were not altered by any of the experimental conditions (bottom). Data are mean \pm SEM. ${ }^{*} p<0.05$ versus extinction. ${ }^{* *} p<0.001$ versus extinction. ${ }^{\circ} p<0.05$ versus cue at WD1. ${ }^{\circ 00} p<0.001$ versus cue at WD1.
}

and confirmed that rAAV-Dnmt3a2-shRNA infusion decreased Dnmt3a2 $\left(t_{(8)}=2.7 ; p=0.02\right)$ but not Dnmt3a1 $\left(t_{(9)}=1.9 ; p=\right.$ 0.1 ) expression (Fig. $4 B$ ). Of the 19 rats entering CSA training, 1 did not acquire CSA, 2 died after surgery, 1 did not reach extinction criteria, and 3 were excluded after histological evaluation of the infusion target; therefore, only 12 animals (5 Dnmt3a2shRNA and 7 controls) were considered for analysis. Dnmt3a2shRNA and control transfected rats had comparable history of cocaine intake $\left(\right.$ day $\times$ groups interaction $\left[F_{(10,100)}=0.8 ; p=\right.$ 0.66]; Fig. 4C). Analysis of active poking during the first hour of extinction found no overall effect of groups $\left(F_{(1,10)}=0.2 ; p=\right.$ $0.68)$, there was an effect of withdrawal $\left(F_{(1,10)}=15.1 ; p=0.003\right)$, but no groups $\times$ withdrawal interaction $\left(F_{(1,10)}=0.0007 ; p=\right.$ $0.98)$, indicating that both control and Dnmt3a2-shRNA groups incubated extinction responding and did not differ from each other (Fig. 4D). ANOVA of cue-induced reinstatement found a nose-poking by reinstatement-phase $\times$ groups interaction $\left(F_{(1,10)}=14.5 ; p=0.0034\right)$ and withdrawal by reinstatementphase $\times$ nose-poking interaction $\left(F_{(1,10)}=7.9 ; p=0.018\right)$. Newman-Keuls analysis revealed that cocaine-paired cues reinstated active nose-poking at both WD1 $(p<0.05)$ and WD45 $(p<$ $0.001)$. In both groups, reinstatement at WD45 was significantly higher than WD1 (control group, $p<0.001$; Dnmt3a2-shRNA group, $p<0.05$ ), indicating incubation of craving. Importantly, groups did not differ in reinstatement score at WD1 $(p=0.88)$; however, at WD45, the Dnmt3a2-shRNA group showed a lower reinstatement score compared with control virus-treated animals $(p<0.05$; Fig. $4 E)$.

\section{Experiment 6}

Experiment 5 demonstrated that Dnmt3a2 influences reinstatement after incubation of cocaine craving. Next, we asked whether Dnmt3a2 expression mediates the primary reinforcing effects of cocaine as well. Therefore, in this experiment, we knocked down Dnmt3a2 expression before CSA training (Fig. 5A). Dnmt3a2shRNA and control transfected rats had comparable acquisition and escalation of cocaine intake (overall effect of days $\left[F_{(11,16)}=\right.$ 8.33; $p<0.00001]$, day $\times$ group interaction $\left[F_{(11,176)}=0.4 ; p>\right.$ 0.05 ]; Figure $5 B$ ). Furthermore, there was no difference between groups in the break point reached in a PR session after $12 \mathrm{~d}$ of CSA training $\left(t_{(16)}=-0.1 ; p>0.05\right)$ (Fig. $5 C$ ). Together, these data indicate that dampening of Dnmt3a2 expression does not alter the primary reinforcing effects of cocaine.

Next, we examined whether knocking down the expression of Dnmt3a2 before cocaine exposure would affect cue-induced reinstatement after acute withdrawal and incubation of cocaine craving. Therefore, after the PR test, rats were subjected to a CSA baseline training before cue-induced reinstatement tests. Two control and two Dnmt3a2-shRNA rats did not meet the extinction criterion or had the catheter blocked during baseline retraining; therefore, further analyses were conducted in 8 Dnmt3a2-shRNA and 6 control rats. Dnmt3a2-shRNA and control rats did not differ in terms of active poking during the first hour of extinction in both WD1 and WD45 tests, and in both groups extinction responding increased over incubation (effect of groups $\left[F_{(1,12)}=0.03 ; p=0.86\right]$, effect of withdrawal $\left[F_{(1,12)}=\right.$ 9.79; $p=0.009]$, group $\times$ withdrawal interaction $\left[F_{(1,12)}=0.01\right.$; $p=0.92]$; Figure $5 D$ ). The analysis of cue-induced reinstatement found no withdrawal by reinstatement condition by nose-poking $\times$ groups interaction $\left(F_{(1,12)}=0.6 ; p>0.05\right)$; however, there was a significant reinstatement condition $X$ groups interaction $\left(F_{(1,12)}=4.97 ; p<0.05\right)$. Newman-Keuls post hoc analysis indicated that, in both groups, and at both WD1 and WD45, presen- 
A

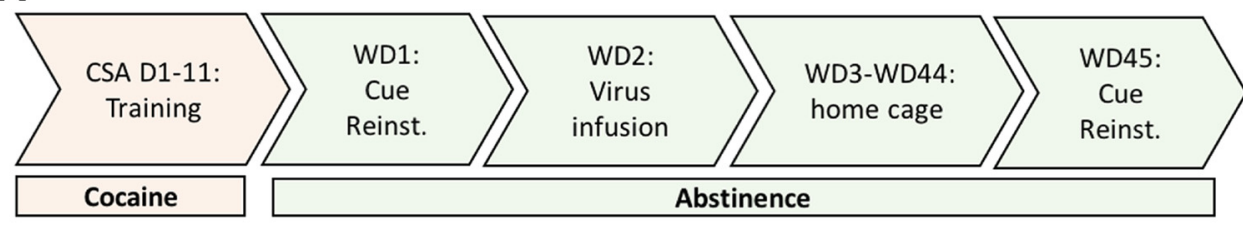

B

$\square$ Control

Dnmt3a2-shRNA
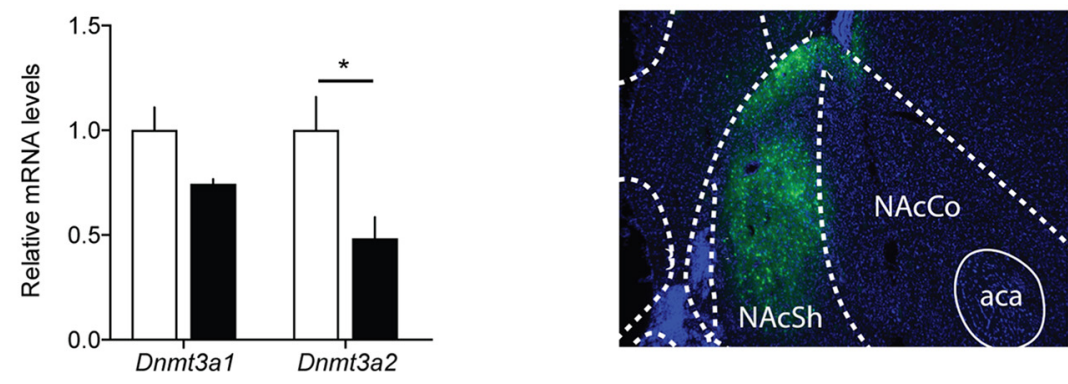

C

CSA training

D

1st hour of extinction
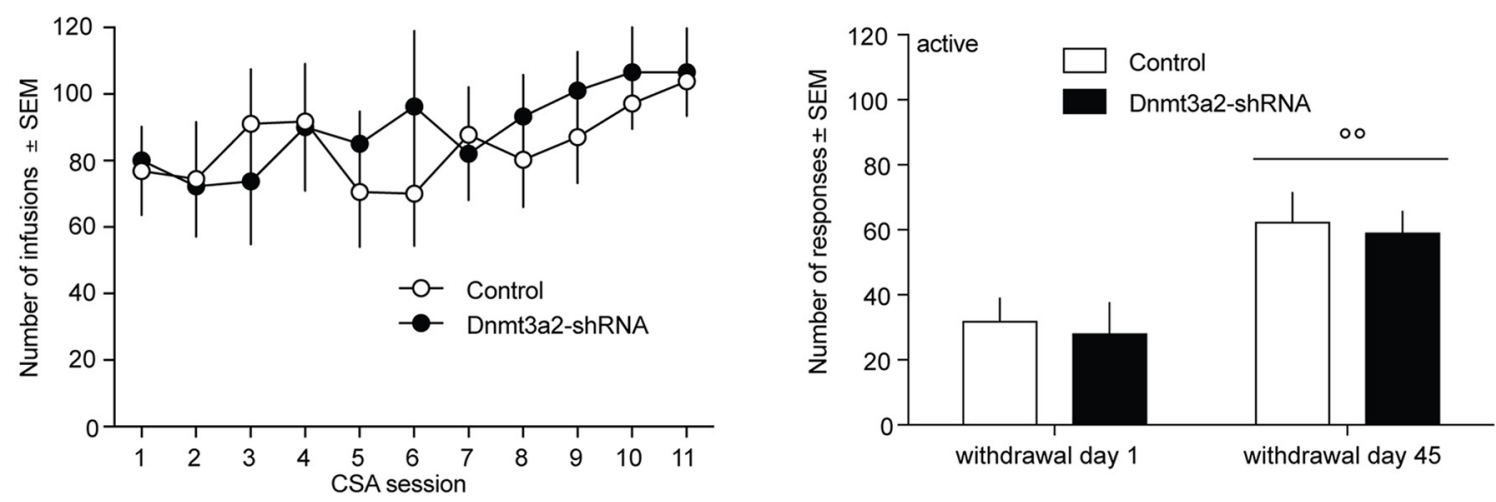

$\mathbf{E}$ Cue-induced reinstatement

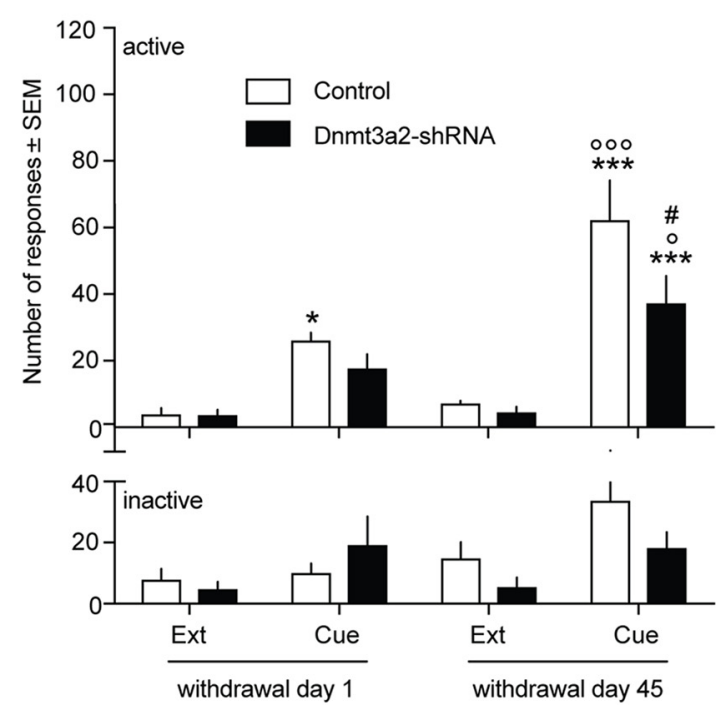

Figure 4. Cue-induced reinstatement in rats infected with rAAV-Dnmt3a2-shRNA and control virus in the NACSh after reinstatement test at WD1. $A$, Schematic drawing of the experimental procedure. $B$, Gene expression analysis of Dnmt3a1 and Dnmt3a2 in the NAcSh after Dnmt3a2 downregulation. rAAV-Dnmt3a2-shRNA infusion decreased Dnmt3a2 but not Dnmt3a1 expression. $N=5$ or $6 /$ group. $C$, Dnmt3a2-shRNA $(n=9)$ and control $(n=10)$ rats did not differ in CSA training performed before infection. D, Dnmt3a2-shRNA and control rats did not differ in active poking during extinction both at WD1 and WD45. Extinction responding incubated in both groups. $E$, During cue-induced reinstatement testing at WD1, before infection, Dnmt3a2-shRNA and control rats did not differ in reinstatement ratio. At WD45, after infection, both groups increased reinstatement ratio in respect to WD1, but reinstatement in Dnmt3a2-shRNA was lower than in control rats. Data are mean \pm SEM. ${ }^{*} p<0.05$ versus extinction. ${ }^{* * *} p<$ 0.001 versus extinction. ${ }^{\circ} p<0.05$ versus cue at WD1. ${ }^{\circ} p<0.01$ versus cue at WD1. ${ }^{\circ 00} p<0.001$ versus cue at WD1. ${ }^{\#} p<0.05$ versus control. 
A

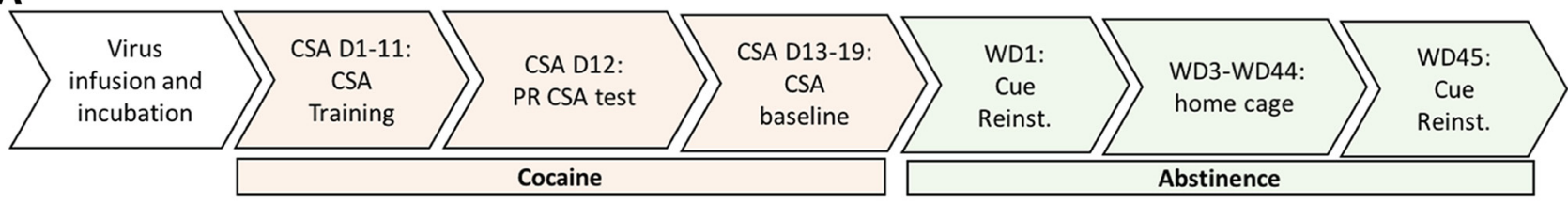

B

CSA training

C

Progressive Ratio
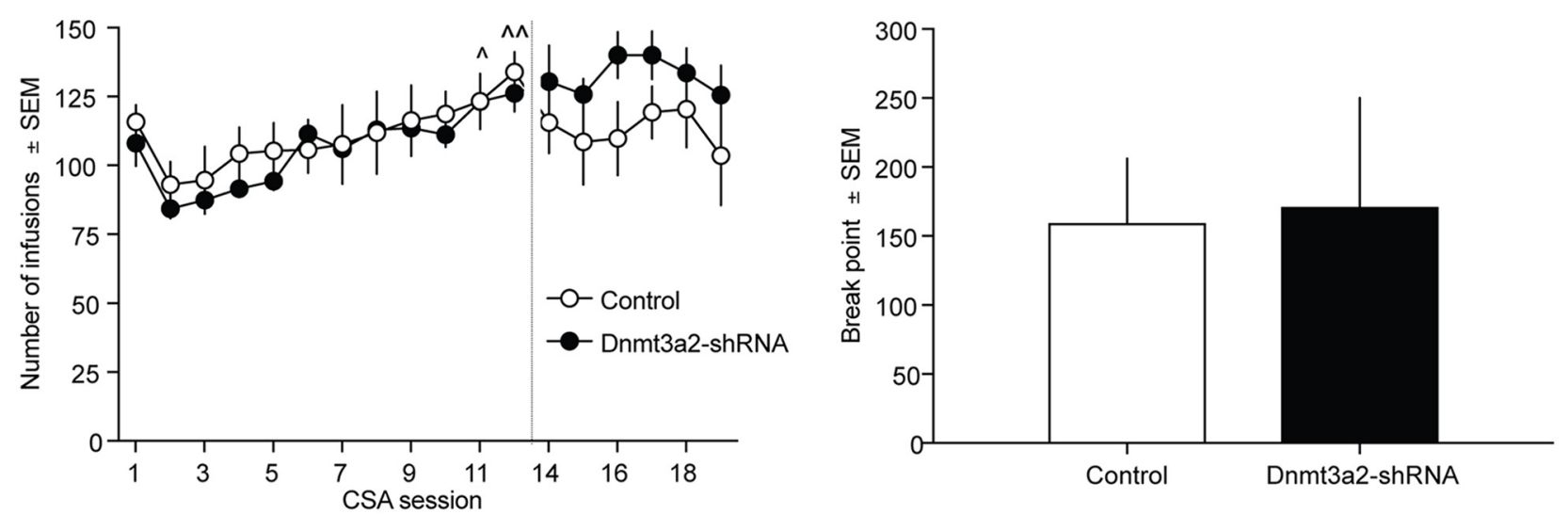

D

1st hour of extinction

E

Cue-induced reinstatement
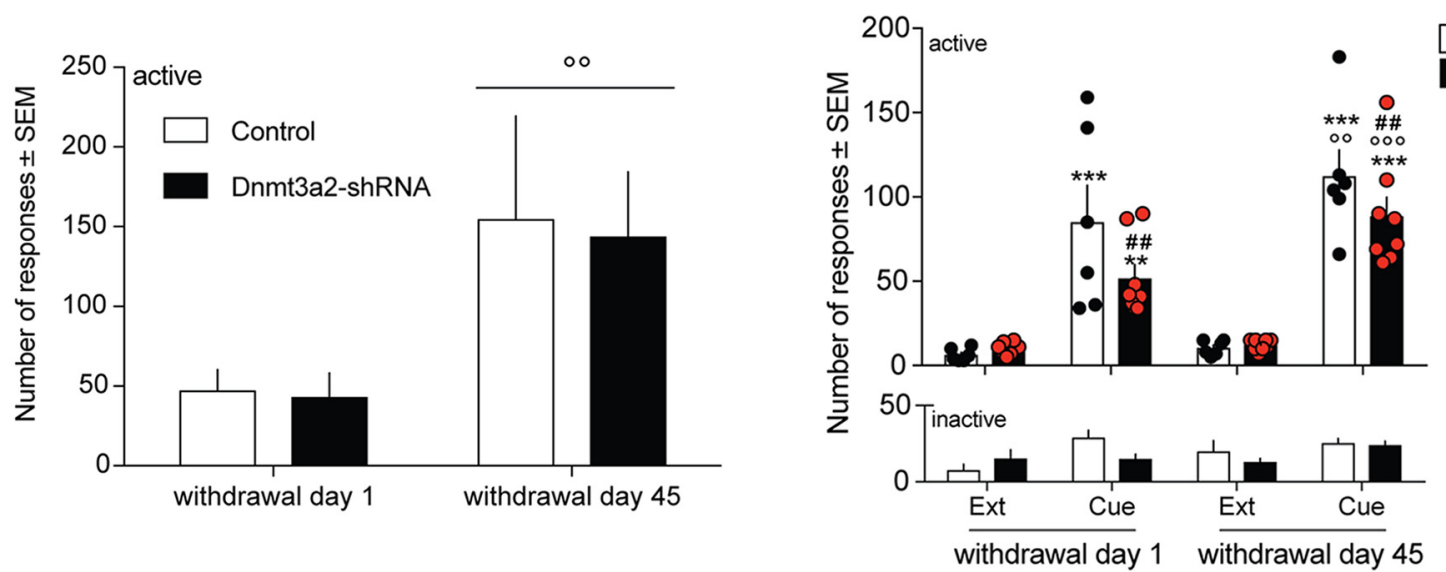

Figure 5. Effect of Dnmt3a2 downregulation on primary reinforcing effects of cocaine and cue-induced reinstatement of cocaine-seeking behavior. $A$, Schematic drawing of the experimental procedure. $\boldsymbol{B}$, Rats treated with Dnmt3a2-shRNA $(n=10)$ did not differ in term of CSA from control $(n=8)$. $\boldsymbol{C}$, The two groups did not differ in motivation for cocaine expressed by the break point reached in a PRsession. After PR, 2 rats per group were excluded from extinction and reinstatement analyses. $\boldsymbol{D}$, Dnmt3a2-shRNA $(n=8)$ and control $(n=6)$ rats did not differ in active poking during extinction both at WD1 and WD45. Extinction responding incubated in both groups. $E$, When cue-induced reinstatement was tested, downregulation of Dnmt3a2 expression reduced reinstatement at WD1 and reinstatement at WD45 remained lower in Dnmat3a2-shRNA treated rats compared with control virus-infected rats. Both groups increased cocaine seeking at WD45 compared with WD1 demonstrating incubation. Black and red dots indicate scatter plot of control and Dnmt3a2-shRNA groups, respectively. Data are mean \pm SEM. $\wedge p<0.05$ versus day 2 of CSA (for both groups). $\wedge \wedge p<0.01$ versus day 2 of CSA (for both groups). ${ }^{* *} p<0.01$ versus extinction. ${ }^{* * *} p<0.001$ versus extinction. ${ }^{\circ 0} p<0.01$ versus cue at WD1. ${ }^{\circ 00} p<0.001$ versus cue at WD1. ${ }^{\# \#} p<0.01$ versus control. ${ }^{\# \#} p<0.001$ versus control.

tation of cocaine-paired cues reinstated active nose-poking in respect to extinction $(p<0.01)$ and that, in both groups, reinstatement at WD45 was higher than WD1 $(p<0.01)$, demonstrating again incubation of cocaine-seeking behavior. Importantly, there was a difference on cue-induced reinstatement on both WD1 and WD45 between the two groups $(p<0.01)$, confirming the results of Experiment 5 and showing that Dnmt3a2 downregulation reduces cue-induced reinstatement of cocaine-seeking after both acute abstinence and incubation of craving (Fig. 5E).

\section{Experiment 7}

Experiments conducted so far demonstrated that Dnmt $3 \mathrm{a} 2$ in the NAcSh influences conditioned reinstatement of cocaine-seeking behavior. Dnmt3a2 has been shown to regulate the expression of plasticity-related genes in the hippocampus (Oliveira et al., 2012, 2016). In this experiment, we therefore examined whether Dnmt3a2 regulates the expression of genes known to be involved in cocaine-dependent neuroadaptations in MSNs. By the use of rAAV-delivered Dnmt3a2-specific shRNA, we reduced the Dnmt3a2 levels in cultured MSNs and assessed the induction of expression of the plasticity genes Arc, FosB, and Egr2 (Fig. 6A). We confirm that Dnmt3a2 (repeated-measures two-way ANOVA effect of time: $\left.F_{(3,12)}=17.09 ; p=0.0001\right)$, Arc (repeated-measures two-way ANOVA effect of time: $F_{(3,12)}=$ 28.52; $p<0.0001$ ), FosB (repeated-measures two-way ANOVA effect of time: $\left.F_{(3,12)}=14.6 ; p=0.0003\right)$, Egr2 
A

Control-shRNA $\square$ Dnmt3a2-shRNA

Dnmt3a2
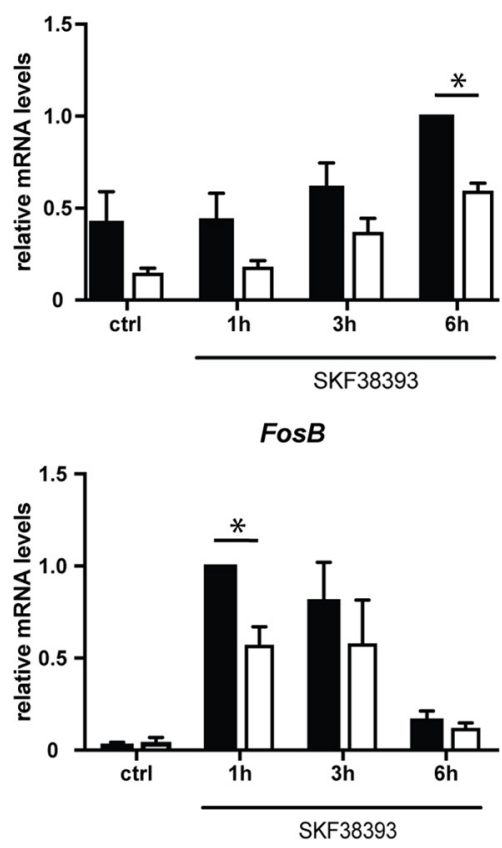

Dnmt3a1

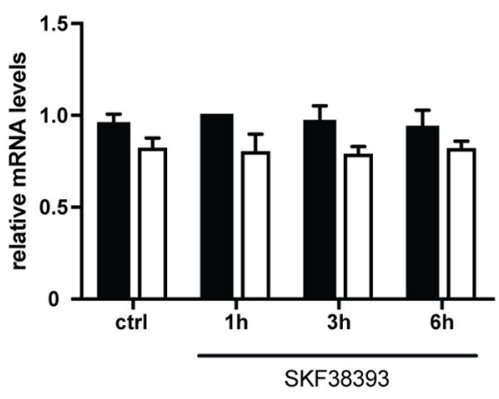

Egr2
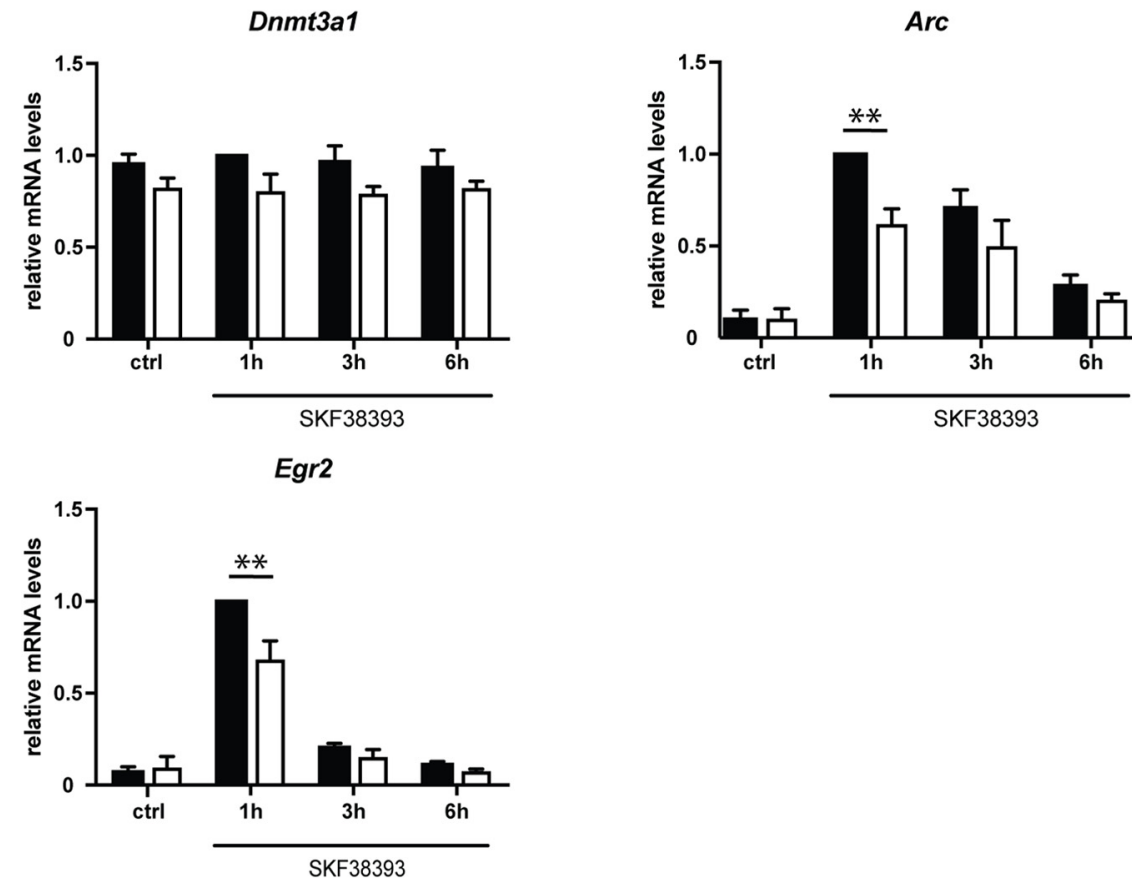

B
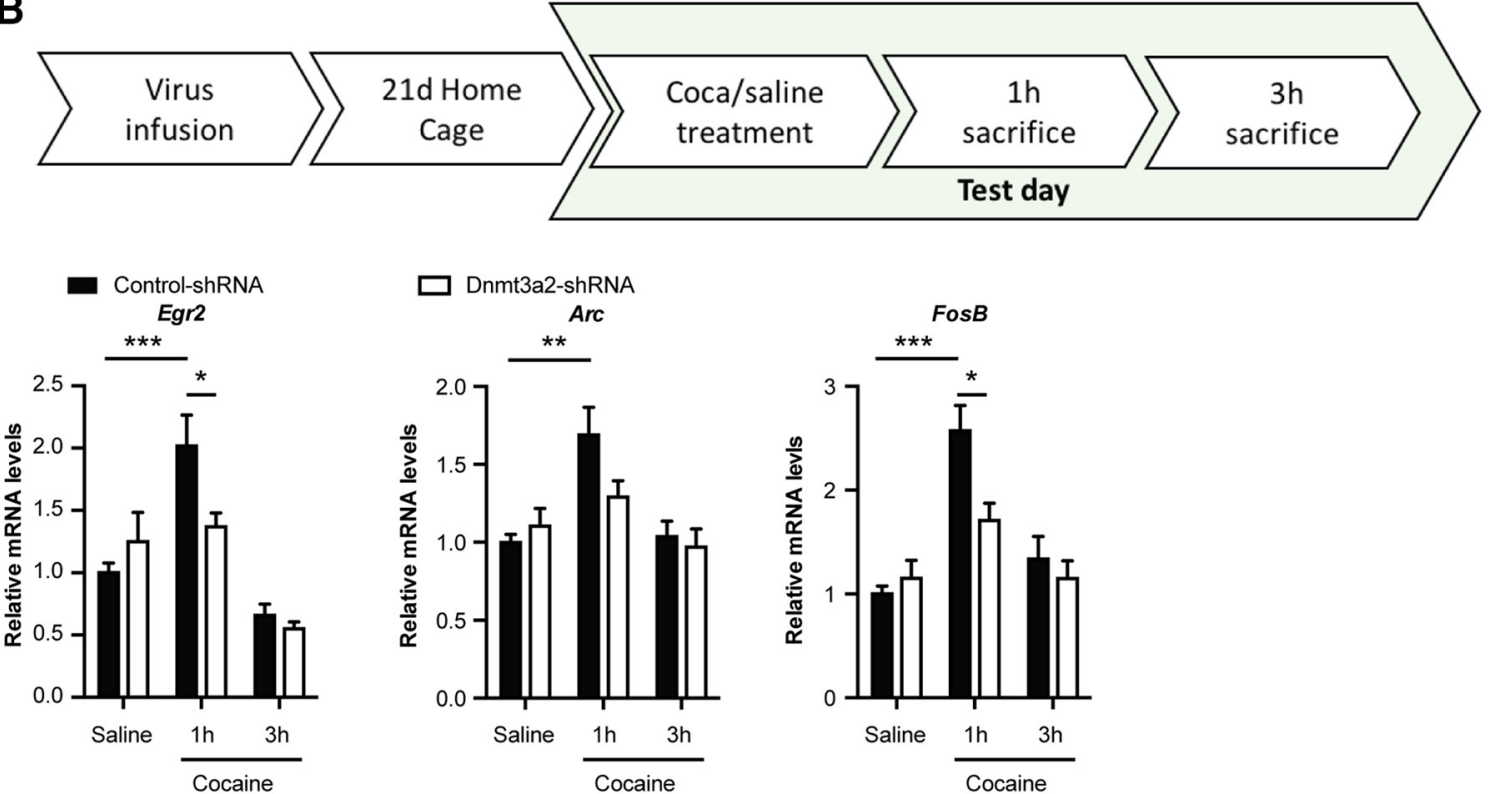

Figure 6. Dnmt3a2-modulated gene expression in cultured MSNs and in the NAcSh. A, Infection of cultured striatal neurons with rAAV-Dnmt3a2-shRNA impairs the expression of Arc, FosB, and Egr2 induced by SKF38393 treatment. The reduced expression of Dnmt3a2, but not Dnmt3a1, in the presence of Dnmt3a2-shRNA confirms the specific knockdown. $N=5$ independent cell preparations. $\boldsymbol{B}$, Top, Representation of the experimental procedure for the acute cocaine challenge. Cocaine-induced expression of plasticity genes was impaired in rAAV-Dnmt3a2-shRNA-injected rats compared with control-injected rats. Arc, Egr2, and Fos $B$ were significantly increased at $1 \mathrm{~h}$, but not $3 \mathrm{~h}$, after cocaine injection. The induction of Egr2 and Fos $B$ was significantly reduced in rats injected with Dnmt3a2-shRNA. For Arc, there was a trend to reduction that was not significant. Saline, $n=13$; cocaine $1 \mathrm{~h}, n=10$; cocaine $3 \mathrm{~h}, n=9$. Data are mean \pm SEM. ${ }^{*} p<0.05$. ${ }^{* *} p<$ $0.01 .{ }^{* * *} p<0.001$.

(repeated-measures two-way ANOVA effect of time: $F_{(3,12)}=$ 84.35; $p<0.0001$ ), but not Dnmt3a1 (repeated-measures twoway ANOVA effect of time: $\left.F_{(3,12)}=0.12 ; p=0.936\right)$ expressions are regulated by D1 receptor activation (Fig. $6 A$, black bars). Moreover, we show that reducing the levels of Dnmt3a2 in the striatal neurons impairs the induction of Arc (virus effect, $F_{(1,4)}=14.4, p=0.0192$; Bonferroni's post hoc test:
control-shRNA1h vs Dnmt3a2-shRNA 1 h: $p=0.0042)$, FosB (virus effect, $F_{(1,4)}=8.358, p=0.0445$; Bonferroni's post hoc test: control-shRNA1h vs Dnmt3a2-shRNA 1 h: $p=0.0064)$, and Egr2 (virus effect, $F_{(1,4)}=15.54, p=0.0169$; Bonferroni's post hoc test: control-shRNA1h vs Dnmt3a2-shRNA $1 \mathrm{~h}: p=$ 0.0007) (Fig. 6A, white bars). This indicates that Dnmt3a2 regulates the expression of these genes. The reduced expres- 
sion of Dnmt3a2 in the presence of the shRNA confirms further the knockdown (Fig. 6A, top left).

\section{Experiment 8}

We hypothesized that, similar to the results obtained with cultured MSNs, Dnmt3a2 may regulate cocaine-induced expression of plasticity genes in the rat NAcSh. To test this, we assessed the expression of plasticity genes in response to acute cocaine in the presence and absence of the Dnmt3a2-shRNA. The results show that $\operatorname{Arc}$ (drug effect, $F_{(2,57)}=11.72, p<0.0001$; Tukey's post hoc test: saline control vs cocaine: $p=0.0005$ ), Fos $B$ (drug effect, $F_{(2,57)}=21.32, p<0.0001$; Tukey's post hoc test: saline control vs cocaine: $p<0.0001$ ), and $E g r 2$ (drug effect, $F_{(2,57)}=28.41, p<$ 0.0001; Tukey's post hoc test: saline control vs cocaine: $p<$ 0.0001 ) expressions are increased at $1 \mathrm{~h}$ after cocaine administration in control conditions (Fig. 6B, black bars). Reducing the levels of Dnmt3a2 in the NAc Shell, by the use of shRNA knockdown, impairs the induction of expression of Egr2 $(p=0.026)$ and FosB $(p=0.0117)$ (Fig. 6B, white bars). This indicates that Dnmt3a2 is required for cocaine-dependent expression of plasticity genes in the rat NAcSh.

\section{Discussion}

In this study, we provide evidence for a role of Dnmt3a2 in conditioned reinstatement of cocaine-seeking behavior after both acute and prolonged withdrawal. The NAcSh appears to be a critical brain site of action of Dnmt3a2 and cocaine-dependent expression of plasticity genes within the NAcSh is dependent on this specific DNA methyltransferase.

\section{Dnmt3a2 expression is regulated by cocaine in NAc shell}

We demonstrate that dopaminergic transmission regulated by the D1 receptor in cultured MSNs increased the expression of Dnmt3a2 but not Dnmt3a1. Similarly, in the ventral striatum of rats that received a noncontingent administration of cocaine, Dnmt3a2, but not Dnmt3a1, expression was increased compared with saline-treated controls. In addition, this effect was specific for the NAcSh as in the NAcCo neither of the Dnmt3a isoforms underwent expression changes induced by cocaine. This is in agreement with previous studies that found that in the NAc the expression of the Dnmt3a gene is upregulated shortly after acute cocaine administration (Anier et al., 2010; LaPlant et al., 2010). We further investigated Dnmt $3 a 2$ and Dnmt3a1 expression in the NAc subdivisions after acute and chronic CSA, and after prolonged withdrawal. We found that acute CSA did not trigger detectable expression changes 24 hours later. Similarly to LaPlant et al. (2010), 24 hours after chronic CSA, we observed a tendency for downregulation of Dnmt3a1 $(p=0.1)$ and Dnmt3a2 $(p=$ 0.1 ) expression in NAcSh; however, in our study, it did not reach statistical significance. In conditions of prolonged abstinence (45 d), the levels of Dnmt3a1 or Dnmt3a2 were unaltered. This finding is in contrast to LaPlant et al. (2010) who found increased expression of the Dnmt3a gene $28 \mathrm{~d}$ after CSA. Differences in the methodology, such as CSA dose and duration of withdrawal, may account for the discrepancy. In our study, we found changes in Dnmt3a2 expression after cue-induced reinstatement. We observed that, when we exposed rats to cue-induced reinstatement, Dnmt3a2 expression was increased but not the Dnmt3a1 isoform. This was restricted to the NAcSh. This suggests that the reinstatement of cocaine seeking is selectively associated with increased Dnmt3a2 expression $24 \mathrm{~h}$ later. It may be that, compared with CSA, cue reinstatement leads to a more prolonged expression that can still be detected at this time point. Alternatively, chronic
CSA may alter the epigenetic landscape of the Dnmt3a gene locus, priming it for transcription activation upon a stimulus, such as cue-induced reinstatement. Consistent with this hypothesis is the observation that chronic CSA leads to hypomethylation of the Dnmt3a gene (Massart et al., 2015). In summary, we found that the expression of Dnmt3a2 is selectively increased in the NAcSh at early time points after cocaine administration and after cueinduced reinstatement. These findings implicate Dnmt3a2 as a possible player in cocaine-driven neuroadaptations.

\section{Dnmt3a2 in NAcSh plays a role in protracted cocaine-seeking behavior}

DNA methylation changes in the NAc have been reported for several genes during incubation of cocaine craving, suggesting that DNA methylation is functionally involved in this process (Massart et al., 2015). Moreover, supplementation of methyl donor increases both cue and cocaine-primed reinstatement of cocaine seeking, whereas Dnmt inhibition decreases cocaine seeking (LaPlant et al., 2010; Massart et al., 2015; Wright et al., 2015). These studies prompted us to investigate whether Dnmt3a2 plays a functional role in cocaine-seeking behavior after prolonged abstinence. We found that rats with reduced levels of Dnmt3a2 in the NAcSh during the withdrawal phase following chronic CSA showed reduced cue-induced reinstatement of cocaine seeking. This finding is in line with Massart et al. (2015) who showed that pharmacological inhibition of Dnmt activity within the NAc abolished cue-induced cocaine seeking after prolonged withdrawal. In our study, reducing the expression levels of a Dnmt3a2 produced a similar effect. Thus, our findings implicate Dnmt3a2 activity in the NAcSh as a possible candidate in the regulation of DNA methylation-dependent events in prolonged withdrawal and drug-seeking behavior. This function is not associated with an increase in the expression levels of this enzyme during abstinence; thus, it is more likely to depend on its activity. Our findings further suggest that targeting Dnmt3a2 activity could alter protracted cocaineseeking behavior.

\section{Dnmt3a2 in the NAcSh contributes to the establishment of cocaine-cue associations}

We found that, when Dnmt3a2 levels in NAcSh are reduced before cocaine training, cue-induced cocaine seeking at WD1 is reduced, an effect that was maintained on WD45. Interestingly, it was shown before that Dnmt inhibition does not affect CSA but reduces cue-induced reinstatement (Massart et al., 2015). In line with these data, rats infected with Dnmt3a2-shRNA before cocaine training showed CSA and progressive ratio responding for cocaine similar to control rats but showed reduced cue-induced reinstatement. In addition, Dnmt3a2-shRNA and control rats did not differ in terms of acute and incubated extinction responding, when the cocaine-associated cues were not presented. Consistently with our finding, Massart et al. (2015) demonstrated that inhibition of DNA methylation decreased cue-extinction responding. Together, this suggests that Dnmt3a2 in the NAcSh contributes to the establishment of cocaine-cue associations, and consequently promotes cocaine seeking induced by cocainepaired stimuli, without influencing the reinforcing properties of cocaine.

Cocaine-induced neuroadaptations that are believed to mediate its addictive effect result from changes in gene expression via activation of D1 receptors (Cadet et al., 2010). Consistently with previous data (Fosnaugh et al., 1995; Larson et al., 2010; Gao et al., 2017), we found three IEGs (Arc, FosB, and Egr2) to be upregulated in striatal MSNs by D1 stimulation and in the NAcSh by 
cocaine. Notably, Arc, FosB, and Egr2 are players in synaptic adaptation and memory consolidation (Poirier et al., 2007; Solecki et al., 2008; Shepherd and Bear, 2011) and are expressed in neuronal ensembles associated with context-induced drug seeking and drug challenge (Cruz et al., 2015). We found that the expression of these IEGs triggered by D1 receptor activation in MSN culture or cocaine in vivo is diminished in rAAV-Dnmt3a2shRNA-infected rats. It is important to note that the stimulusdriven expression of $A r c$, FosB, and Egr2 precedes the one of Dnmt3a2. This indicates that stimulus-driven Dnmt3a2 should not regulate the expression of the other IEGs triggered by the same stimulus. We propose that, similarly to its role in the hippocampus (Oliveira et al., 2012), Dnmt3a2 in the NAcSh may serve a "gating function" for signal-regulated transcription. Dnmt3a2 is required to maintain a methylation landscape that renders the genome permissive for activity-induced gene expression needed for long-term adaptive changes. Moreover, the stimulus-induced upregulation of Dnmt3a2 expression itself is important to reinforce this function and guarantee optimal response to subsequent stimulus. In other words, if cocaine administration occurs in conditions of reduced Dnmt3a2 levels, the genome is in a less permissive state and the cocaine-driven expression of plasticity-related genes is disrupted. This would impact the formation of drug-cue associations and the establishment of neuroadaptations that underlie compulsive drug taking and persistent drug-seeking behavior. The idea that DNA methylation may result in permissive conditions for transcriptional responses may seem counterintuitive at first. However, it is now well accepted that the relationship between DNA methylation and transcription is complex. Several studies have shown poor correlation between DNA methylation and transcriptional changes, with the exception that increases in DNA methylation at gene promoters often leads to transcription repression (Guo et al., 2011; Li et al., 2014; Massart et al., 2015). Therefore, a conceptual framework that is emerging postulates that DNA methylation primes the genome for external stimulus responses (Baker-Andresen et al., 2013, 2015; Massart et al., 2015; Oliveira et al., 2016). The Massart et al. (2015) findings support this idea by showing that a subset of genes that changed DNA methylation status during incubation only underwent transcriptional changes upon presentation of the cocaine-associated cue. Together, our data and published evidence suggest that Dnmt $3 \mathrm{a} 2$ in the NAcSh regulates the consolidation of cocaine-related memories, likely by setting the conditions for cocaine-dependent neuroadaptations, which is then reflected by the ability of environmental stimuli to trigger cocaine seeking after both acute and prolonged withdrawal.

A possible concern on our study could be the choice of agematched naive control animals instead of saline-yoked control rats. However, previous studies on cocaine withdrawal and incubation that used both saline-yoked and age-matched control did not show any difference between the two control groups (Moussawi et al., 2009; Ferrario et al., 2011). In the two previous studies addressing the role of Dnmt3a on cocaine reinforcement, relapse, and incubation, LaPlant et al. (2010) make no description of saline yoking procedure, although the use of naive control is also not clearly stated, whereas Massart et al. (2015) used saline-yoked controls. Both studies found specific effects of cocaine on Dnmt3a expression and methylation. Noteworthy, as we discussed above, there is a clear overlap between ours and the results of Massart et al. (2015), suggesting that the different control animals used did not influence the results.
In conclusion, our study uncovered a role for Dnmt3a2 in cueinduced reinstatement of cocaine seeking in NAcSh. Dnmt3a2 plays a role in protracted cue-induced reinstatement and in the mediation of the association between cocaine and environmental cue without affecting the primary reinforcing effects of cocaine but inducing long-lasting adaptations that mediate reinstatement. Therefore, targeting Dnmt3a2 may be an approach to reduce cocaine craving and relapse.

\section{References}

Adhikary S, Caprioli D, Venniro M, Kallenberger P, Shaham Y, Bossert JM (2017) Incubation of extinction responding and cue-induced reinstatement, but not context- or drug priming-induced reinstatement, after withdrawal from methamphetamine. Addict Biol 22:977-990. CrossRef Medline

Anier K, Malinovskaja K, Aonurm-Helm A, Zharkovsky A, Kalda A (2010) DNA methylation regulates cocaine-induced behavioral sensitization in mice. Neuropsychopharmacology 35:2450-2461. CrossRef Medline

Bading H, Greenberg ME (1991) Stimulation of protein tyrosine phosphorylation by NMDA receptor activation. Science 253:912-914. CrossRef Medline

Baker-Andresen D, Ratnu VS, Bredy TW (2013) Dynamic DNA methylation: a prime candidate for genomic metaplasticity and bahavioral adaptation. Trends Neurosci 36:3-13. CrossRef Medline

Baker-Andresen D, Zhao Q, Li X, Jupp B, Chesworth R, Lawrence AJ, Bredy TW (2015) Persistent variations in neuronal DNA methylation following cocaine self-administration and protracted abstinence in mice. Neuroepigenetics 4:1-11. CrossRef Medline

Bedi G, Preston KL, Epstein DH, Heishman SJ, Marrone GF, Shaham Y, de Wit H (2011) Incubation of cue-induced cigarette craving during abstinence in human smokers. Biol Psychiatry 69:708-711. CrossRef Medline

Cadet JL, Jayanthi S, McCoy MT, Beauvais G, Cai NS (2010) Dopamine D1 receptors, regulation of gene expression in the brain, and neurodegeneration. CNS Neurol Disord Drug Targets 9:526-538. CrossRef Medline

Cannella N, Cosa-Linan A, Roscher M, Takahashi TT, Vogler N, Wängler B, Spanagel R (2017) [18F]-Fluorodeoxyglucose-positron emission tomography in rats with prolonged cocaine self-administration suggests potential brain biomarkers for addictive behavior. Front Psychiatry 8:218. CrossRef Medline

Cannella N, Cosa-Linan A, Büchler E, Falfan-Melgoza C, Weber-Fahr W, Spanagel R (2018) In vivo structural imaging in rats reveals neuroanatomical correlates of behavioral sub-dimensions of cocaine addiction. Addict Biol 23:182-195. CrossRef Medline

Chen T, Ueda Y, Xie S, Li E (2002) A novel Dnmt3a isoform produced from an alternative promoter localizes to euchromatin and its expression correlates with active de novo methylation. J Biol Chem 277:38746-38754. CrossRef Medline

Conrad KL, Tseng KY, Uejima JL, Reimers JM, Heng LJ, Shaham Y, Marinelli M, Wolf ME (2008) Formation of accumbens GluR2-lacking AMPA receptors mediates incubation of cocaine craving. Nature 454:118-121. CrossRef Medline

Cruz FC, Javier Rubio F, Hope BT (2015) Using c-fos to study neuronal ensembles in corticostriatal circuitry of addiction. Brain Res 1628:157173. CrossRef Medline

Day JJ, Childs D, Guzman-Karlsson MC, Kibe M, Moulden J, Song E, Tahir A, Sweatt JD (2013) DNA methylation regulates associative reward learning. Nat Neurosci 16:1445-1452. CrossRef Medline

Ferrario CR, Loweth JA, Milovanovic M, Ford KA, Galiñanes GL, Heng LJ, Tseng KY, Wolf ME (2011) Alterations in AMPA receptor subunits and TARPs in the rat nucleus accumbens related to the formation of $\mathrm{Ca}^{2+}$. permeable AMPA receptors during the incubation of cocaine craving. Neuropharmacology 61:1141-1151. CrossRef Medline

Fosnaugh JS, Bhat RV, Yamagata K, Worley PF, Baraban JM (1995) Activation of arc, a putative "effector" immediate early gene, by cocaine in rat brain. J Neurochem 64:2377-2380. CrossRef Medline

Gao P, Limpens JH, Spijker S, Vanderschuren LJ, Voorn P (2017) Stable immediate early gene expression patterns in medial prefrontal cortex and striatum after long-term cocaine self-administration. Addict Biol 22:354 368. CrossRef Medline

Gawin FH, Kleber HD (1986) Abstinence symptomatology and psychiatric 
diagnosis in cocaine abusers. clinical observations. Arch Gen Psychiatry 43:107-113. CrossRef Medline

Grimm JW, Hope BT, Wise RA, Shaham Y (2001) Neuroadaptation. Incubation of cocaine craving after withdrawal. Nature 412:141-142. CrossRef Medline

Guo JU, Ma DK, Mo H, Ball MP, Jang MH, Bonaguidi MA, Balazer JA, Eaves HL, Xie B, Ford E, Zhang K, Ming GL, Gao Y, Song H (2011) Neuronal activity modifies the DNA methylation landscape in the adult brain. Nat Neurosci 14:1345-1351. CrossRef Medline

Halder R, Hennion M, Vidal RO, Shomroni O, Rahman RU, Rajput A, Centeno TP, van Bebber F, Capece V, Garcia Vizcaino JC, Schuetz AL, Burkhardt S, Benito E, Navarro Sala M, Javan SB, Haass C, Schmid B, Fischer A, Bonn S (2016) DNA methylation changes in plasticity genes accompany the formation and maintenance of memory. Nat Neurosci 19:102-110. CrossRef Medline

LaPlant Q, Vialou V, Covington HE 3rd, Dumitriu D, Feng J, Warren BL, Maze I, Dietz DM, Watts EL, Iñiguez SD, Koo JW, Mouzon E, Renthal W, Hollis F, Wang H, Noonan MA, Ren Y, Eisch AJ, Bolaños CA, Kabbaj M, et al. (2010) Dnmt3a regulates emotional behavior and spine plasticity in the nucleus accumbens. Nat Neurosci 13:1137-1143. CrossRef Medline

Larson EB, Akkentli F, Edwards S, Graham DL, Simmons DL, Alibhai IN, Nestler EJ, Self DW (2010) Striatal regulation of DeltaFosB, FosB, and cFos during cocaine self-administration and withdrawal. J Neurochem 115:112-122. CrossRef Medline

Li P, Wu P, Xin X, Fan YL, Wang GB, Wang F, Ma MY, Xue MM, Luo YX, Yang FD, Bao YP, Shi J, Sun HQ, Lu L (2015) incubation of alcohol craving during abstinence in patients with alcohol dependence. Addict Biol 20:513-522. CrossRef Medline

Li X, Wei W, Zhao QY, Widagdo J, Baker-Andresen D, Flavell CR, D'Alessio A, Zhang Y, Bredy TW (2014) Neocortical Tet3-mediated accumulation of 5-hydroxymethylcytosine promotes rapid behavioral adaptation. Proc Natl Acad Sci U S A 111:7120-7125. CrossRef Medline

Loweth JA, Tseng KY, Wolf ME (2014) Adaptations in AMPA receptor transmission in the nucleus accumbens contributing to incubation of cocaine craving. Neuropharmacology 76:287-300. CrossRef Medline

Luís C, Cannella N, Spanagel R, Köhr G (2017) Persistent strengthening of the prefrontal cortex-nucleus accumbens pathway during incubation of cocaine-seeking behavior. Neurobiol Learn Mem 138:281-290. CrossRef Medline

Massart R, Barnea R, Dikshtein Y, Suderman M, Meir O, Hallett M, Kennedy P, Nestler EJ, Szyf M, Yadid G (2015) Role of DNA methylation in the nucleus accumbens in incubation of cocaine craving. J Neurosci 35:80428058. CrossRef Medline

Miller CA, Gavin CF, White JA, Parrish RR, Honasoge A, Yancey CR, Rivera IM, Rubio MD, Rumbaugh G, Sweatt JD (2010) Cortical DNA methylation maintains remote memory. Nat Neurosci 13:664-666. CrossRef Medline

Moore LD, Le T, Fan G (2013) DNA methylation and its basic function. Neuropsychopharmacology 38:23-38. CrossRef Medline

Moussawi K, Pacchioni A, Moran M, Olive MF, Gass JT, Lavin A, Kalivas PW (2009) N-Acetylcysteine reverses cocaine-induced metaplasticity. Nat Neurosci 12:182-189. CrossRef Medline
Nestler EJ (2013) Cellular basis of memory for addiction. Dialogues Clin Neurosci 15:431-443. Medline

Oberhofer J, Noori HR (2017) Quantitative evaluation of cue-induce reinstatement model for evidence-based experimental optimization. Addict Biol. Advance online publication. Retrieved. doi: 10.1111/adb.12588. CrossRef

O’Brien CP, Childress AR, Mclellan TA, Ehrman R (1992) Classical conditioning in drug dependent humans. Ann N Y Acad Sci 654:400-415. CrossRef Medline

Oliveira AM (2016) DNA methylation: a permissive mark in memory formation and maintenance. Learn Mem 23:587-593. CrossRef Medline

Oliveira AM, Hemstedt TJ, Bading H (2012) Rescue of aging-associated decline in Dnmt3a2 expression restores cognitive abilities. Nat Neurosci 15:1111-1113. CrossRef Medline

Oliveira AM, Hemstedt TJ, Freitag HE, Bading H (2016) Dnmt3a2: a hub for enhancing cognitive functions. Mol Psychiatry 21:1130-1136. CrossRef Medline

Parvaz MA, Moeller SJ, Goldstein RZ (2016) Incubation of cue-induced craving in adults addicted to cocaine measured by electroencephalography. JAMA Psychiatry 73:1127-1134. CrossRef Medline

Paxinos G, Watson C (1998) The rat brain in stereotaxic coordinates, Ed 4. San Diego, CA: Academic.

Poirier R, Cheval H, Mailhes C, Charnay P, Davis S, Laroche S (2007) Paradoxical role of an egr transcription factor family member, Egr2/Krox20, in learning and memory. Front Behav Neurosci 1:6. CrossRef Medline

Robison AJ, Nestler EJ (2011) Transcriptional and epigenetic mechanisms of addiction. Nat Rev Neurosci 12:623-637. CrossRef Medline

Rudenko A, Tsai LH (2014) Epigenetic modifications in the nervous system and their impact upon cognitive impairments. Neuropharmacology 80: 70-82. CrossRef Medline

Shaham Y, Shalev U, Lu L, de Wit H, Stewart J (2003) The reinstatement model of drug relapse: history, methodology and major findings. Psychopharmacology 168:3-20. CrossRef Medline

Shepherd JD, Bear MF (2011) New views of arc, a master regulator of synaptic plasticity. Nat Neurosci 14:279-284. CrossRef Medline

Solecki W, Krowka T, Kubik J, Kaczmarek L, Przewlocki R (2008) Role of fosB in behaviours related to morphine reward and spatial memory. Behav Brain Res 190:212-217. CrossRef Medline

Spanagel R (2017) Animal models of addiction. Dialogues Clin Neurosci 19:247-258. Medline

Wang G, Shi J, Chen N, Xu L, Li J, Li P, Sun Y, Lu L (2013) Effects of length of abstinence on decision-making and craving in methamphetamine abusers. PLoS One 8:e68791. CrossRef Medline

Wright KN, Hollis F, Duclot F, Dossat AM, Strong CE, Francis TC, Mercer R, Feng J, Dietz DM, Lobo MK, Nestler EJ, Kabbaj M (2015) Methyl supplementation attenuates cocaine-seeking behaviors and cocaine-induced c-fos activation in a DNA methylation-dependent manner. J Neurosci 35:8948-8958. CrossRef Medline

Zhang SJ, Steijaert MN, Lau D, Schütz G, Delucinge-Vivier C, Descombes P, Bading H (2007) Decoding NMDA receptor signaling: identification of genomic programs specifying neuronal survival and death. Neuron 53 : 549-562. CrossRef Medline 